\title{
La voz documento en la cultura de la imagen
}

\author{
Ignacio TAMÉs GARCÍA \\ tamesignacio@yahoo.es
}

Recibido: 03/04/2014

Aceptado: 20/05/2014

\section{RESUMEN}

Reflexiones sobre el documento y lo documental en la cultura cinematográfica: Se revisa la obra de Robert Flaherty y de John Grierson y las aportaciones de Federico García Lorca, Salvador Dalí y Luis Buñuel.

Palabras clave: Documento, Cine documental, Salvador Dalí, Federico García Lorca, Luis Buñuel, Robert Flaherty

Reflections on the meaning of the word "document" and documentary film culture

\begin{abstract}
The work of Robert Flaherty and John Grierson and the contributions of Federico García Lorca, Salvador Dalí and Luis Buñuel is reviewed.

Keywords: Document, Documentary Film, Salvador Dalí, Federico García Lorca, Luis Buñuel, Robert Flaherty
\end{abstract}

La adaptación de un relevante conjunto de avances tecnológicos en el terreno de la reproducción de la imagen y el sonido para el consumo individual a gran escala -cámaras fotográficas, magnetófonos, televisiones, reproductores de video...causó, sobre todo a partir de los años cincuenta y sesenta del siglo pasado, una seria alteración en el papel -nunca mejor dicho- que las leyes tenían reservado para el uso de la voz documento. En los años veinte y treinta del siglo pasado ${ }^{1}$ se comenzó a utilizar el término documento -o document, o dokument-para referirse a las imágenes grabadas que representasen la vida cotidiana de seres humanos (con

1 SÁNCHEZ VIGIL, Juan Miguel El universo de la fotografia. Prensa, edición, documentación. Madrid Espasa-Calpe 1999 pág. 29. 
frecuencia con una forma de vida alejada y distinta de la vida urbana moderna) para referirse a la reproducción de imágenes que captasen sucesos bélicos o imágenes violentas, lejanos para el receptor del mensaje y para referirse a las imágenes y la voz de propaganda de los gobiernos de los países que tuviesen a la guerra como una realidad o una amenaza inmediata y dispusiesen de los medios técnicos necesarios para desarrollar una estrategia informativa ${ }^{2}$ o ya, si se quiere, documental.

Robert Flaherty en Estados Unidos (Nanook of the North, 1922, Moana, 1926) su colaboradora Frances Flaherty y John Grierson (Drifters, 1929) en el Reino Unido utilizaron en los años veinte la palabra document o documental para denominar y construir el armazón teórico literario que realizaron para presentar sus propias películas cinematográficas -o fotografías de paso a veinticuatro fotogramas por segundo- y en el Museo de Arte Moderno de Nueva York se creó un departamento de la imagen denominado Documentalism Department. Allí trabajaría Luis Buñuel en 1941, al ser incorporado al equipo de documentalistas gracias, entre otros factores, a que los Flaherty se hallaban maravillados por su película Las Hurdes / Tierra sin pan ${ }^{3}$. John Grierson, por su parte, se hallaba integrado en Inglaterra en la unidad denominada Unidad G.P.O. y continuó sus actividades en un departamento del antiguo Directorio Comercial del Imperio -The Empire Marketing Board- como responsable del entrenamiento de los directores y de la producción de películas, presentadas y teorizadas por él mismo como documentales en publicaciones especializadas. El destino de esas películas era dar publicidad a las empresas gubernamentales y coloniales con el objetivo de interesar y de educar al público británico en lo referente a la vida en comunidad como reflejo -o contestación- a los logros, en ese terreno, de Serguei Eisenstein en la URSS. En Rusia se había reconocido antes que en Inglaterra y en el resto del mundo anglosajón que el cine es capaz de excitar la mente del público, dando realidad a sus ojos a las innumerables actividades que contribuyen al bienestar, aunque los espectadores no vean nunca a la mayoría de los demás ciudadanos que cooperan con ellos en dar vida al conjunto de la sociedad. Así se procuró hacer nacer en cada país una conciencia colectiva o ciudadana de las penurias sufridas por los menos afortunados y la idea de que había que compartirlas con el esfuerzo de todos ${ }^{4}$.

${ }^{2}$ EMERY, Edwin y EMERY, Michael. The Press and America, An Interpretative History of the Mass Media Englewood Cliffs Prentice-Hall Inc, 1988 pág. 390-391

${ }^{3}$ SÁNCHEZ VIDAL, Agustín. "De las Hurdes a Tierra sin pan". Las Hurdes/Tierra sin pan. Un documental de Luis Buñuel Madrid Junta de Extremadura, 2000. Pág. 52 y 55 y ss. Iris Barry, la directora de la Filmoteca del MoMA había entregado la película a Robert Flaherty y así lo cuenta a Luis Buñuel en una carta muy reveladora de la que más adelante nos ocuparemos.

${ }^{4}$ SPOTTISWOODE, Raymond. Gramática del cine. Buenos Aires Ediciones Losange, 1958. Pág. 49 y 160. 
La utilización de la voz documento por la cinematografía derivaba de la utilización de la voz por la fotografía, pero en la fotografía la aplicación del vocablo a determinadas fotografías no derivaba de una construcción teórica que realizasen los creadores como Flaherty, Grierson o Buñuel sobre su propia obra y la manera que utilizaron de presentarla a los gobiernos y al público de cada naciónestado. Tuvo otro origen. Pero fueron estos creadores, actuando más como teóricos antes que como filmadores, más como escritores y oradores, antes que como creadores visuales quienes, ciertamente, utilizaron esta palabra y no otra para designar un conjunto significativo de películas o trabajos cinematográficos al servicio de las respectivas industrias e intereses de los gobiernos y administraciones de los distintos países involucrados en el contexto de la génesis de la Segunda Guerra Mundial y de su preludio, la Guerra Civil española. Es decir, antes de la Guerra Civil española y de la Segunda Guerra Mundial la palabra ya se hallaba bien asentada y numerosas películas se exhibían en las salas, de las más elegantes a las menos, con el nombre de documentales, pero al igual a lo que sucede con el vocablo en su contexto jurídico, nadie podía precisar con certeza qué es lo que fuera un documento aunque se hicieran documentales o se fuese a ver un documental; pues, como refería Raymond Spottiswoode, podía apreciarse que el alfarero hace vasijas, y el documentalista, documentales; aunque: "ya sabíamos lo que es una vasija pero todavía no sabemos nada de un documental", ya que, los que se han ocupado de ello, añade, eluden dar una definición clara de eso. Él, discretamente propone una "El film documental es, por su tema y tratamiento, una presentación dramatizada de la relación del hombre con la vida institucional, ya sea industrial, social o política; y en su técnica, una subordinación de la forma al contenido"s.

John Grierson, el creador de Drifters en 1929 sobre la esforzada vida de los pescadores o de Industrial Britain en 1933 -cuyo propósito era nada menos que demostrar que detrás de la producción en cadena lo que de verdad cuenta es la tarea del artesano-. se refería al documental cinematográfico, por el contrario -es decir, a su propio trabajo cinematográfico al servicio del gobierno británico- de manera más abierta, como "el tratamiento creativo de lo actual". Acaso podamos deducir del contexto de su actividad cinematográfica y crítica que, cualquier cosa, por alejada de la idea de Spottiswoode que se nos antojara, podría ser merecedora de la atención de las necesidades de la propaganda del gobierno, de la administración o de la industria asociada, y así habría de ser tratada creativamente por el documentalista para hacer nacer en el público receptor del mensaje el efecto adecuado a las necesidades del momento.

\footnotetext{
${ }^{5}$ SPOTTISWOODE, Raymond. Op. cit Gramática del... Pág. 164-167.

${ }^{6}$ SPOTTISWOODE, Raymond. Op. cit Gramática del... Pág. 164. Cita la definición de John Grierson como publicada en Cinema Quaterly (Vol. 2, Núm. 1 pág. 8)
} 


\section{LA DIALÉCTICA DEL DOCUMENTO ESCRITO Y LA DEL DOCUMENTO DE LA IMAGEN}

Podemos afirmar, de modo un tanto intuitivo, que nadie hubiera calificado, hasta mediados del siglo XX a Las meninas o a la Novena Sinfonía de Beethoven como documentos. El vocablo de raíz "doc", en todo caso, se percibía hasta entonces -es decir hasta el período de entreguerras del siglo pasado- tan sólo dentro de la cultura del texto escrito, pero no en la de la reproducción visual o acústica. El medio de prueba documento o documental era, en esencia -en España por las indefinición de las leyes procesales y por el uso social- un texto escrito y no un cuadro, un madrigal, una película o una fotografía "(luego una cinta de cassete, un video etc...) A consecuencia de ello, durante un dilatado período de tiempo, se dieron situaciones ambiguas y contradictorias entre unos tribunales y otros con relación a la admisión o no admisión de elementos no escritos como elementos probatorios que mostrasen un hecho, un acto o una situación cuya existencia se quisiera demostrar mediante la reproducción acústica o visual. Es decir, su relación a su admisión o no como medios de prueba, capaces, por tanto, de rivalizar y vencer en un juicio al texto escrito por una mayor fuerza persuasiva. La retórica de la imagen rivalizó así con la retórica o poder de convicción que emanaba del texto escrito y de la elocuencia oratoria.

En España sólo con la Ley de Enjuiciamiento Civil de 7 de enero de 2000 se llegó, no obstante -ya en el presente siglo- a reconocer para la ley, para seguir la práctica de la gran mayoría de los tribunales, que los medios de prueba audiovisuales y demás medios de reproducción de la imagen, el sonido y la palabra, tuviesen fuerza en un juicio, es decir, fuesen pruebas, a efectos legales, porque el poder público estatal hubo de hacer frente ya a un adversario de mucha más consideración que cámaras de fotos, vídeos y hasta televisiones privadas: el ordenador personal conectado a una red de información audiovisual de ámbito mundial o global. Ya no cabía dilatar la regulación de la materia, pues era preciso cumplir con un objetivo: regular e integrar el ordenador personal, los sistemas telemáticos y la transmisión de la información en la red para no dejar a la organización de juzgados y tribunales genuinamente al margen de un proceso que trasciende las fronteras de todos los estados incluidos obviamente sus juzgados y tribunales- pues, a su lado, parecen más pequeños y menos activos de lo que acaso sean.

Este vertiginoso proceso de multiplicación de la información que se transmite bajo muy diversos soportes, que hemos procurado exponer someramente, no es otra cosa que una parte del tema de este artículo. En la Ley de Enjuiciamiento Civil de 2001, de nuevo, no se define ontológicamente lo que sea o no sea un documento. La indefinición que empleó el legislador del siglo XIX español en esta materia se mantiene actualmente, y al abordar los documentos se los clasifica, y también describe, sí, pero eso ya dentro de sus respectivas especies, es decir, sin llegar a definir ni a tratar el género: "A efectos de prueba en el proceso, se consideran documentos públicos: 1. Las resoluciones y diligencias de..." $\mathrm{O}$ bien 
"se consideran documentos privados, a efectos de prueba en el proceso, aquéllos que..."7. Y en relación a los medios de reproducción audiovisuales se les tiene como prueba, pero no se les distingue como una especie de los comprendidos en esa categoría genérica:

También se admitirán, conforme a lo dispuesto en esta Ley, los medios de reproducción de la palabra, el sonido y la imagen, así como los instrumentos que permiten archivar y conocer o reproducir palabras, datos, cifras y operaciones matemáticas llevadas a cabo con fines contables o de otra clase, relevantes para el proceso ${ }^{8}$.

Todo ello no es sencillo, en tanto que es materia interdisciplinar. La locución documento, para la ley, es tan polisémica y compleja como lo es en el mundo no técnico jurídico, pero acaso sea suficiente para que podamos apreciar que la voz que nos ocupa se utiliza hoy en día en los procesos judiciales con un significado propio y, al tiempo, esa misma voz se emplea en el mundo no técnico o no especializado con diversos significados, muy diferentes según cada contexto.

\section{APROXIMACIÓN A LA DIALÉCTICA DEL DOCUMENTO Y LA FICCIÓN}

La voz documento es una palabra que se puede cruzar -no necesariamente oponer- con la voz "ficción" en relación a dos países -España e Inglaterra- y fijando textualmente dicha relación es posible precisar que en 1897, ocho años después de que se publicara como ley el Código Civil para España y Ultramar, el jurista irlandés Bram Stoker publicó en Londres su conocida obra de ficción Drácula, en la que apenas se utiliza -ni obviamente se define- la palabra documento, puesto que sólo se emplea en la breve nota final con la que concluye la popular novela:

I took the papers from the safe where they had ever been since our return so long ago. We were struck with the fact, that in all the mass of material of which the record is composed, there is hardly one authentic document, nothing but a mass of type-writing, except the later notebooks of Mina and Seward and myself, and Van Helsing's

${ }^{7}$ Art. 317 y 324 de la Ley de Enjuiciamiento Civil de 7 de enero de 2001.

${ }^{8}$ Art. 299. 2 de la Ley de Enjuiciamiento Civil de 7 de enero de 2001. Y el apartado 3 del artículo deja las puertas abiertas a la admisión de medios de prueba: "Cuando por cualquier otro medio no expresamente previsto en los apartados anteriores de este artículo pudiera obtenerse certeza sobre hechos relevantes, el tribunal, a instancia de parte, lo admitirá como prueba, adoptando las medidas que en cada caso resulten necesarias". 
memorandum. We could hardly ask any one, even did we wish do, to accept these as proofs of so wild story. [...] Jonathan Harker. ${ }^{9}$

En un periodo de tiempo en el que los avances tecnológicos son vertiginosos y se dan problemas en la vida tenida por real para determinar qué sea cierto o qué no sea cierto de cada hecho, de cada acto o situación que se produce en el mundo, un jurista, Bram Stoker, escribe un texto que, ciertamente -por cómo está editado, cómo se titula, cómo se compone la portada, etc...-, se presenta al público como una obra de ficción. Al final del mismo, sin embargo, escindiéndose significativamente del conjunto que compone el resto del texto, surge una duda relevante y conclusiva para algunos de los protagonistas. Sólo entonces, al plantear la duda de alguno de ellos sobre si lo que ha sucedido es verdadero o falso, es ficción o es realidad, para ellos mismos, surge la palabra que ahora nos ocupa: documento y no antes. Se trata de un recurso del autor, sí, pero es algo que puede hacer que nos interroguemos acerca del por qué de ello, tratándose el autor de un jurista experimentado, pues sucede que en los veintisiete capítulos que conforman el cuerpo del texto no aparece mencionada ni una sola vez dicha palabra. Y, sin embargo, podemos apreciar que la casi totalidad de los elementos escritos que orientan y hacen avanzar el argumento, hoy -y en el momento de su composiciónson tenidos por tales documentos -dado el actual peso polisémico de la palabra en nuestros días junto a muchos otros entonces inexistentes-, por el hablante coloquial, los tribunales, los periódicos, etc... Es posible que se trate de una casualidad y que Stoker, efectivamente, pudiera acaso haber utilizado la palabra documento desde el capítulo 1, titulando incluso a cada capítulo como documento 1, 2, 3 y así hasta 27: o no utilizarla en absoluto, pero no lo hizo: sólo utilizó el citado vocablo en la nota final, cuando los propios personajes, juzgadores ya de lo asombroso de la trama en la que se vieron inmersos -según la nota final después de transcurrido un tiempo desde los hechos-, se sintieron asaltados por la incertidumbre de su propio juicio... juicio que se da ante sus propios actos y que se produce ante la presencia escrita de sucesos y situaciones increíbles que, de un modo u otro, quedaron incorporados y reunidos en cartas, actas, cintas de fonógrafos, diarios personales taquigrafiados, recortes de periódicos, diarios de barcos, telegramas etc... Es posible que se trate de una mera casualidad el que se utilizase dicha palabra en la conclusiva nota final, pero es muy improbable que así fuera o, al menos, esa es la opinión de este investigador. Stoker era jurista con bastante experiencia y la composición del texto le llevó algunos años de estudio en los que pocas cosas quedaron al azar. Nada de ello tiene que ver -conviene advertirlo de algún modo-, con la agilidad con la que se ha leído y se lee el texto de la novela, pues esa es una virtud que se deriva del exhaustivo trabajo previo del

${ }^{9}$ STOKER, Bram. Dracula. Nueva York New American Library.1965.pág. 382. Letra en negrita del autor de este artículo. 
autor $^{10}$. Las numerosas notas manuscritas que se conservan en el Museo y Biblioteca Rosenbach de Filadelfia son fiel reflejo de ese proceso creativo que ha sido tratado por muy diversos escritores e investigadores del mundo anglosajón y de diversos ámbitos, desde los más profundos a otros más divulgativos.

\section{TEXTO ESCRITO, IMAGEN Y FICCIÓN EN LOS TEXTOS LEGALES DE LA CODIFICACIÓN ESPAÑOLA}

En 1882, cuando el entonces jurista Bram Stoker tenía treinta y tres años y trabajaba en Dublín al servicio de la administración británica, se publicó en España, como texto legal, la Ley de Enjuiciamiento Criminal, en la que -sin llegar a definir ontológicamente, como en las otras leyes vistas, la voz que nos ocupa-, se regulaba el procedimiento que se hubiese de seguir en la persecución y en el enjuiciamiento de los delitos y faltas que se cometiesen. Fue, después de la Ley de Enjuiciamiento Civil de 1881, la siguiente gran tarea legislativa de renovación profunda a la que se entregaron la Comisión General de Codificación y las Cortes tras la restauración canovista: urgía regular -antes de dictar el Código Civil de 1889-, cómo se perseguían y enjuiciaban los ilícitos penales ${ }^{11}$ por los juzgados y tribunales del Estado.

El Juez de instrucción -el funcionario responsable para la investigación de los delitos que se cometen-, dirige en España la investigación que ha de constar por escrito en un expediente: un conjunto de textos que deben ordenarse cronológicamente según van aconteciendo los actos, hechos o situaciones en los que consiste materialmente la investigación que él mismo va ordenando o inquiriendo. Ese expediente se denomina sumario.

${ }^{10}$ BELDFORD, Barbara. Bram Stoker A Biography of the Author of Dracula Londres Phoenix Giant \& Orion Books Ltd, 1997, 261. "Only the vampire speaks in the narrative form, all other information is filtered through written documents. Stoker makes clear the purpose of these overlapping texts in an anonymous preface (of the omitted from some modern texts): "There is throughtout no statement of past things wherein memory may err, for all the records chosen are exactly contemporary, given from the standpoints and within the range of knowledge of those who made them." In a brilliant touch, he enhances the present tense by featuring new inventions such as rhe Kodak camera, the portable typewriter, and the recording phonograph." He utilizado así las fuentes que se pueden considerar más próximas al original de estas notas, antes que cualquiera de las muchas obras divulgativas que sobre esta materia existen en inglés, en español, o en otros idiomas.

${ }^{11}$ La Ley de Enjuiciamiento Criminal de 1882 sigue vigente en la regulación del proceso penal para la investigación y enjuiciamiento de los ilícitos penales. Se viene preparando, no obstante, un nuevo texto legal procesal penal de nueva planta en el que, entre otras materias, tendrá que abordarse la regulación de los nuevos avances tecnológicos que se han producido en las últimas décadas. Es de suponer que, de promulgarse una nueva ley procesal penal, se regulará qué se pueda considerar un documento o qué no lo sea en el orden jurisdiccional penal. 
En lo que concierne a nuestro tema podemos apreciar que en la investigación de los delitos se reguló expresamente que el Juez de instrucción podría acordar el registro de libros y de papeles y la apertura de la correspondencia escrita ${ }^{12}$, la telegráfica y la escucha de las comunicaciones telefónicas ${ }^{13}$. Pero esos textos no se denominan documentos sino libros y papeles ${ }^{14}$. La prestigiosa locución que nos ocupa sólo se utiliza en la investigación para referir o designar los papeles o libros de funcionarios, es decir, sólo cuando se está investigando la comisión de un delito por una persona integrada en la función pública ${ }^{15}$. Sólo en ese caso los textos ajenos al proceso son tenidos por documentos pero, en cuanto a todos los demás papeles y libros de interés para la investigación, se establece que:

El Juez recogerá los instrumentos y efectos del delito, y podrá recoger también los libros, papeles o cualesquiera otras cosas que se hubiesen encontrado, si esto fuere necesario para el resultado del sumario. Los libros y papeles que se recojan serán foliados, sellados y rubricados en todas sus hojas por el Juez, por el Secretario, por el interesado o los que hagan sus veces, y por ${ }_{16}$ las demás personas que hayan asistido al registro.

La fotografía no se menciona y, sin embargo, era utilizada de hecho por la policía en la identificación de delincuentes comunes, de prostitutas o de enemigos políticos. Las primeras escuelas oficiales existentes en España dedicadas a la enseñanza de las técnicas fotográficas fueron las de la policía de Madrid y Barcelona, antes que las que se dedicaron a la enseñanza de las mismas técnicas, pero aplicadas a las artes. Ese fue el resultado de aplicar a los delincuentes comunes $^{17}$, a las prostitutas, y a una difusa gama de enemigos políticos las técnicas de identificación fotográfica creadas y teorizadas por Alphonse Bertillon (18531914) y el doctor Cesare Lombroso (1835-1909) aunque la fotografía no fuese documento en un juicio criminal... ni en uno civil... ¿Cómo es posible esto? Ciertamente, sorprende, pero tiene su explicación, que no se halla en las leyes escritas o en un área del conocimiento que, a su vez, no sea interdisciplinar. En vano buscaremos en las leyes codificadas la respuesta -quizás sólo la pregunta

12 Art. 579 y 586 de la Ley de Enjuiciamiento Criminal.

13 Mediante la escucha, grabación y posterior transcripción escrita de las conversaciones, después documentadas e incorporadas al sumario por el Secretario judicial, aunque también puedan ser reproducidas luego en el juicio por los medios que las registraron. Fue la experiencia en la investigación antes que la regulación normativa la que condujo a esa técnica de trabajo..

14 Art. 546 y 550 de la Ley de Enjuiciamiento Criminal.

15 Art. 335 de la Ley de Enjuiciamiento Criminal.

16 Art. 574 y 575 de la Ley de Enjuiciamiento Criminal.

17 SÁNCHEZ VIGIL, Juan Miguel Op. Cit. El universo de la fotografía... Pág. 65. 
implícita-, pues sólo la crítica de las artes nos permitirá atisbar el por qué de esa rigurosa contradicción que se ha asumido por la sociedad durante más de un siglo sin apenas reacción alguna, pues, verdaderamente, se trata de una contradicción, pero está construida sobre unas bases sólidas:

Cuando hablamos de documentación y noticias no estamos dejando de lado las imágenes fruto de la práctica fotográfica, sino todo lo contrario, las estamos leyendo conjuntamente a los textos que ilustran. Un análisis aislado de las imágenes sería inútil y aquí se propone, precisamente, la lectura simultánea de los textos y las imágenes en su ubicación original: revistas, anuarios, catálogos de salones, libros, carteles publicitarios y otros. A partir de esta literatura fotográfica compuesta por la publicación de textos, de imágenes y, también, de textos con imágenes y de imágenes con textos, se debería llegar a comprender que la fotografía no tan sólo se mira sino que sobre todo se lee. ${ }^{18}$

La clave acaso podamos encontrarla en esta idea de la doctora Elisabet Insenser, que se halla integrada en la introducción a su tesis La fotografía en España en el periodo de entreguerras (1914-1939). Con esta idea podemos comprender que la fotografía se considera documento para la ley sólo por una vía alternativa a la que pueda corresponder a un texto escrito, de tal manera que sólo es tal documento cuando la imagen es integrada en un archivo policial, en un sumario de un juzgado, en un procedimiento administrativo etc... Cuando, en definitiva, es leída, interpretada y utilizada por un responsable público que ha procedido a integrarla en un contexto escrito, y no en otro, de tal manera que el texto del expediente y la mera imagen se complementan adecuadamente para los intereses que corresponda defender. La lectura simultánea de texto escrito e imagen produce un efecto diferente a la mera imagen proyectada del negativo sobre un papel: no es lo mismo ver una fotografía de una persona, sin más, que ver una fotografía de una persona integrada en un sumario judicial, en un expediente administrativo o en una revista de publicación periódica. En un nivel más general que el jurídico o el ficcional una fotografía sin texto escrito tiene ciertas probabilidades de no ser aceptada por quien haya de integrarla en un archivo, un expediente o una publicación ${ }^{19}$.

La ausencia de referencias en los textos legales a la fotografía ${ }^{20}$-que arrastrará luego al cine y al video- condujo a que sólo los funcionarios al servicio del circuito

18 INSENSER, Elisabet. La fotografia en España en el periodo de entreguerras (19141939) Gerona CCG Ediciones \& Centre de Recerca i Difusió de la Imatge del Ajuntament de Girona, 2001. Pág. 10. Letra en negrita del autor de este artículo.

19 VALLE GASTAMINZA, Félix del. El análisis documental de la fotografía. http://pendientedemigracion.ucm.es/info/multidoc/prof/fvalle/artfot.htm Universidad Complutense de Madrid, Versión 2001. Consulta: 15-4-2014. Apartado 2: "Polimorfismo de la imagen: Relación imagen-texto. Los reportajes".

20 Art. 726 y 741 de la Ley de Enjuiciamiento Criminal. 
inquisitivo del Estado pudiesen utilizarla -mediante el sencillo mecanismo de utilizarla de hecho- a través del mecanismo de controlar y permitir el acceso de las fotografías pertinentes a los archivos, los sumarios, los expedientes... al texto escrito, en definitiva, en el que se produce la investigación, el proceso. Su no mención o elusión es así un intento de exortizar un mecanismo transcriptor de la realidad potencialmente peligroso. No se le menciona, pero eso no quiere decir que no se le utilice. Más aún, si en un juicio se quisiera utilizar como medio de prueba por una persona no integrada en el circuito inquisitivo el rechazo, su inadmisión como prueba cuando es utilizado por otro, si conviniere, estaría discretamente justificada: no se menciona a la fotografía como documento, como medio de prueba, por lo que cualquier reacción cabe, quedando abierto el camino para el comportamiento arbitrario del responsable público -el juez de instrucción, el fiscal, el secretario judicial, etc...- que hubiere de decidir en cada momento del proceso si hace pasar o no una fotografía al sumario, al expediente, al juicio. Cualquier decisión queda así amparada ante cada situación, ante cada fotografía -después cada video o película- relacionada con cada texto escrito no imaginado o ilustrado, o leído, con esos medios técnicos.

En los tribunales de España fueron los propios magistrados quienes, muy posteriormente, ante el vacío legal de las leyes procesales, fueron admitiendo progresivamente las fotografías, pero, ingeniosamente, no calificándolas directamente como documentos (eso hubiera supuesto entrar en una probable contradicción con la ley) sino considerándolas como parte de las pruebas periciales y testificales que se celebrasen en los juicios, pero sólo en el caso de que las fotografías se quisiesen hacer valer por un testigo o por un perito de una determinada materia para dar mayor credibilidad y soporte a sus declaraciones. Se evitaba así llamarlas documentos, pero se admitían en el contexto de otras pruebas. Las fotografías llegaron así a ser pruebas testificales o periciales, en tanto que fuesen presentadas en el contexto de las respectivas declaraciones de los peritos con conocimientos, artísticos o técnicos que fuesen llamados al juicio o de testigos presenciales de los hechos. No fue un proceso sencillo y uniforme, y no sería fácil para un investigador de hoy en día determinar los procedimientos en los que una fotografía -y luego un video, o una cinta de cassete- pudo resultar esclarecedora y, sin embargo, no fue admitida en el caso -las cifras negras del problema-, o existiendo ni se pensó por los afectados en utilizarla como documento o soporte de sus afirmaciones. Es decir, no se trata de buscar culpables, sino de referir la evolución, en dos países, de un problema que es antropológicamente complejo.

\section{TEXTO ESCRITO, IMAGEN Y FICCIÓN PARA LA JURISPRUDENCIA INGLESA VICTORIANA}

Podríamos interpretar lo visto, en buena parte, como una reacción de la cultura escrita, y de sus intereses creados, frente a la cultura de lo visual y sus nuevos 
focos de poder. No se ha de dejar de relacionar lo expuesto con uno de los rasgos con los que el jurista irlandés Stoker dota a la encarnación del mal por el mal: es imposible fotografiarlo como un ser vivo. Stoker en las notas previas ${ }^{21}$ que elaboró para caracterizar su personaje utilizó marginalmente la palabra Kodak, para apuntar que el negativo fotográfico le hace aparecer de una manera que no representa la figura de un ser vivo, sino más bien la de un esqueleto, como si la fotografía fuese una radiografía, y lo hace -entre 1890 y 1896- justo después de que, en 1888, la casa Kodak pusiera a la venta su primera cámara para aficionados ${ }^{22}$. El lema que la empresa norteamericana utilizó en la publicidad de la novedosa cámara Kodak número 1 fue "you press the button, we do the rest" y así se difundió desde América a Europa, permitiendo a cualquiera que la comprase no muchos inicialmente- obtener la imagen fotográfica sin hacer los complicados procesos químicos que hasta entonces habían sido necesarios. Bastaba solicitar previo pago de una modesta cantidad- a la empresa vendedora - un nuevo foco de poder-el revelado del negativo.

Stoker atribuyó al conde Drácula, en ese contexto, la condición de ser que no se refleja en los espejos y que, por tanto, tampoco podría ser fotografiado por una cámara, evitándose quizás algún grave problema que se le iba a producir como creador del personaje y evitando también -algo que tiene ver con lo que se plantea- calificar a la fotografía como documento, en la nota final del texto. Obviamente, es sólo escritura lo que le da el ser textual y, si atendemos a ello, veríamos que ninguna de las películas cinematográficas posteriormente creadas son, según el relato original, ontológicamente posibles puesto que el protagonista principal no se deja captar fielmente por las cámaras; aunque sea de suponer que los directores o los guionistas no planteasen ese problema a los productores pendientes de beneficios en las salas comerciales.

El legislador español también pensó en algo parecido con relación a la fotografía mejor ni mencionarla y que sea utilizada por los funcionarios en lo que convenga a cada momento, a cada situación, pero no textualizarla -no legislarla- y así no quedar comprometido ${ }^{23}$ en denominarla con la prestigiosa locución documento, porque ello obligaría a tener por tal documento no sólo las fotografías que realicen o interesen a los servicios públicos en el ejercicio de sus funciones,

21 EIGHTEEN-BISANG, Robert / MILLER, Elizabeth Bram Stoker's Notes for Dracula. A Facsimile Edition. Philadelphia Rosenbach Museum \& Library Mc Farland, 2008. Contents all 124 pages of the original notes in .facsimile. Transcriptions of all pages, annotations and commentary. Es preferible en todo caso utilizar en esta materia las fuentes originales en facsímil, antes que las publicaciones divulgativas o secundarias.

22 TORRES, José Manuel. La retina del sabio. Fuentes documentales para la historia de la Fotografía Científica en España. Santander Aula de Fotografía y de la Imagen de la Universidad de Cantabria \& Ayuntamiento de Gerona, 2001. Pág. 79.

23 Contrasta en España el silencio respecto a la fotografía con la mención expresa de los telegramas y del teléfono en la Ley de Enjuiciamiento Criminal de 1882 (artículo 579) que, en todo caso, concluyen en ser textos escritos, o transcritos, pero sin imágenes. 
sino a cualquier fotografía hecha por cualquier persona... Y empleó así una técnica narrativa elusiva, pero eficaz y que demuestra que no estamos precisamente ante un ignorante de la persuasión por elusión aunque sí de alguien -al menos en esos momentos de la codificación liberal-, algo contradictorio en algunos aspectos jurídicos relevantes.

En Inglaterra, siguiendo las consecuencias de la amplia comercialización de los productos de la industria estadounidense, la trayectoria fue diferente debido a que la actuación de los jueces, tribunales y jurados fue dando paso gradualmente a la utilización de la fotografía por muy diversas personas ${ }^{24}$, no servidores públicos, como documentos, o si se quiere, pruebas, en los juicios, dependiendo la suerte que corriese cada fotografía de que fuese admitida o no en cada juzgado, tribunal, o jurado ante quien se hubiese de presentar, lo cual no se habría de considerar ni mejor ni peor. En los casos denominados de primera impresión o primera decisión como fueron los primeros en los que se pretendió utilizar fotografías como pruebas, los jueces no pudieron hallar una autoridad específica que les guiase, y tuvieron que crear la decisión, la nueva norma o precedente del case law por primera vez para cada asunto, aunque decidiesen sobre consideraciones que su preparación profesional les inclinase a pensar como consecuente con los principios generales del Derecho anglosajón ${ }^{25}$. La limitación del Derecho casuístico es su rigidez y retraso con relación con relación a las condiciones sociales cambiantes. A medida que los diversos asuntos fueron llegando a los tribunales superiores especialmente al Tribunal de Apelación y a la Cámara de los Lores- los criterios se irían unificando paulatinamente. Es sólo otra manera de establecer las normas. No fue necesario que el poder público comprometiese directamente su voz legislativa en unas leyes expresas que tuvieran que pronunciarse precisamente sobre la consideración general y para todos obligatoria -como en el sistema español o continental- de lo visual fotográfico como documental y probatorio. Probablemente, de haber tenido que hacerlo no hubieran adoptado una actitud diferente a la elusiva actitud del legislador hispano, pero los pasos no fueron sencillos porque el cambio es demasiado severo: la esencia científica de la fotografía no contradice, en este final del siglo XIX, su empleo en el campo de la ficción, incluso de la magia y el delirio. Para Didi Huberman el valor de autentificación sirve con mucha frecuencia la causa de un valor de revelación. La

${ }^{24}$ CARR, Edward Hallet What is History? Londres Penguin Books, 1964. Pág. 143144. "In Great Britain our passion for gradualism is such that the movement is sometimes scarcely perceptible. We have rested on the laurels of universal elementary education for the best part of a century, and have still not advanced very far or very quickly towards universal higher education [...] The revolution, which you may call a social revolution, but which I call in the present context the expansion of reason, is only just beginning. But it is advancing at a staggering pace to keep abreast of the staggering technological advances of the last generation".

25 ALLEN, Carleton Kemp Las fuentes del Derecho inglés. Madrid Instituto de Estudios Políticos, 1969. Pág. 528-529. 
fotografía no se contenta con reproducir lo visible, produce también objetos visibles ideales (aspecto demiúrgico en cierto modo) al tiempo que los demuestra experimentalmente (aspecto positivista). Se llegó a calificar como optograma a las fotografías de la imagen retiniana de los fallecidos por asesinato, o por muerte violenta y esta técnica se llegó a utilizar en medicina legal, pretendiendo así captar la imagen del asesino reflejada en la retina de la víctima. ${ }^{26}$ La actitud de Stoker, un jurista, empleado público o civil servant, perteneciente y educado en la cultura del proceso escrito ante la fotografía -un no documento en su conocida novela-, es reveladora.

Fue así la industria fotográfica $-\mathrm{y}$ a la vez, como hemos visto la cinematográfica-, la que comenzó en los años veinte del siglo pasado a utilizar, en foros ajenos a los procesos judiciales y a las organizaciones específicamente administrativas, la voz documento en revistas y publicaciones especializadas de las artes para beneficiarse -sobre todo con fines publicitarios- del prestigio del vocablo y para amparar también así la existencia real de ficticias representaciones gráficas de las vacaciones, las comidas de trabajo, los cuadros, las pinturas, las despedidas, los paisajes, etc... En definitiva, de todo tipo de imágenes y sucesos, artísticos y estéticos o no, de la vida cotidiana, por las inevitables consecuencias: las fotografías, que acarreaba la utilización de las cámaras. Desde su invención, instituciones, particulares y luego medios de comunicación se sirvieron de la fotografía, y luego de la cinematografía, para justificar, demostrar o ilustrar cualquier hecho y museos, sociedades fotográficas, e investigadores científico experimentales $^{27}$ la utilizaron con un fin que ahora ya se denomina documental. Pero dicho fin no se corresponde con una tendencia teleológica precisa, sino que, si se trata o se identifica con un fin, éste, en realidad, abarca muchos fines diversificados. Como consecuencia de ello, la aplicación de la palabra documento a la imagen fotográfica y a la cinematográfica no ha estado exenta de graves tensiones. He procurado resaltar de esta manera los puntos más conflictivos de un problema, de un tema que es necesariamente interdisciplinar. La invención de la imagen fotográfica, y luego de la cinematográfica, no se produjo por servidores o funcionarios públicos vinculados a la escritura, ni mucho menos por juristas, políticos o historiadores, sino más bien por creadores y visionarios precursores que bebían en las fuentes de la alquimia y los experimentos químicos. La creación posterior de grandes archivos de información en las agencias y periódicos o incluso particulares, desde que se comenzaron a publicar fotografías en revistas periódicas y diarios a finales del siglo XIX produjo que se generase luego un debate, en el periodo de entreguerras, sobre cual fuese el valor de autentificación de la fotografía $\mathrm{y}$ del cine, y las palabras documento, ficción y realidad tuvieron gran protagonismo. La aplicación de la palabra documento a las imágenes fotográficas o

${ }^{26}$ TORRES, José Manuel. Op. cit. La retina del sabio... Pág. 18 y 27.

27 TORRES, José Manuel. Op. cit. La retina del sabio... Pág. 163,164 y 173. 
cinematográficas fue así abriéndose paso con rapidez, pero también con dificultades ${ }^{28}$ por las implicaciones políticas que ello tenía.

Hoy ya parecen quedar lejos estos problemas al haber sido integradas esas imágenes en el ciclo documental, en el circuito del poder informativo, ya compartido entre los medios de comunicación y las administraciones públicas occidentales entre las que, obviamente, se hallan tanto la española como las que tienen a la lengua inglesa como su lengua ${ }^{29}$. Tratándose la materia tan sólo de algunos de los aspectos más conflictivos del problema, si hemos de tener en cuenta que los medios de comunicación han alcanzado un estatuto tan propio de las instituciones como cualquier otro foco de poder público. Existen así los departamentos de Documentalismo en las Universidades, las imágenes fotográficas y cinematográficas documentadas -mejor diremos para evitar la tautología integradas- en toda clase de instituciones y organismos públicos -museos, fundaciones, archivos públicos etc...- pero el camino hasta ello ha sido dificultoso.

\section{DOCUMENTO Y FICCIÓN EN EL PERIODO DE ENTREGUERRAS. ALGUNOS ARTISTAS: SU PERCEPCIÓN DE LOS CLÁSICOS EUROPEOS DEL SIGLO XVII.}

Una fotografía de una mesa no es una mesa ${ }^{30}$. Es la fotografía de una mesa. Una fotografía de un cuadro no es un cuadro. Es la fotografía de un cuadro. Es evidente. Pero lo evidente y lo sencillo no son lo mismo. Una nueva mirada que arranque de nuestro interior puede bastar para mirar las cosas de otro modo al que normalmente estemos acostumbrados o enseñados pues se puede hacer de lo que se presenta a nuestros ojos un nuevo mundo complejo. Eso es sencillo de entender, pero no evidente, en tanto que quizás no se percibe mediante la vista, sino que hay que leerlo o interpretarlo. Cualquiera que sepa leer despacio y con juicio, no obstante, puede entender que oír y ver son cosas diferentes que se complementan. Eso es leer

${ }^{28}$ SÁNCHEZ VIGIL, Juan Miguel Op. cit. El universo de la fotografía...Pág. 27-28. Sobre las primeras fotografías en prensa diaria (1.897 New York Times y en España El Gráfico 1904) Pág. 91.

${ }^{29}$ Sobre el origen positivista, la diversificación y la fragmentación del concepto de Otlet en las Ciencias de la Documentación véase, por ejemplo, entre otros del mismo autor: LÓPEZ YEPES, José. La documentación como disciplina: teoría e historia. Pamplona. EUNSA, 1995; o LÓPEZ YEPES, José (coord.) Manual de Ciencias de la Documentación. "Documentación" Pág. 39-73. Ediciones Pirámide, 2002.

${ }^{30}$ DALÍ, Salvador "Els meus quadros del saló de Tardor". En L`Amic de les Arts Siges núm. 19 octubre 1927: Addició al núm. 19: "Saber mirar un objecte, un animal, d’una manera espiritual, és veure'l en la seva máxima realitat objectiva. La gent, però, veu tan sols imatges estereotipades de les coses, pure ombres buides d'expressió, purs fantasmes de les coses, i trova vulgar tot el que té el costum de presenciar freqüentement, per maravellós i miraculós que sigui. Per aixó he escrit recentement, en parlar de la fotografía: Mirar es inventar". 
en un sentido último, muy profundo, aunque al final sencillo: la vista y el oído pueden actuar en nuestra consciencia recíprocamente y así han de hacerlo en toda lectura, el uno con la otra.

La aparición del cinematógrafo en las distintas capitales europeas y occidentales concluyó en que la voz documento terminara por aplicarse, coincidentemente, tanto a películas cinematográficas como a fotografías fijas y se produjo un debate sobre el valor documental -no judicial o institucional-. de las mismas. El cénit de las polémicas se produjo en los años veinte y treinta del siglo pasado. Lo escrito y lo visual rivalizaron así hasta un extremo hasta entonces no concebible, al hacerse posible la perspectiva y la reflexión sobre la aplicación y la utilidad de los ya no tan nuevos inventos. Se trataba de delimitar su utilidad, su valor, su función social, y de calificar y de enmarcar su poder de persuasión para las masas, de precisar sus posibilidades para la creación artística y de determinar el lugar que les habría de corresponder en la jerarquía de la sociedad. Es decir podía asentarse -como se hizo- que la fotografía no fuese pintura o que el cine no fuese teatro, todo ello dentro del mero esteticismo y la forma, mas al tener otras enormes posibilidades para las artes, la industria y la política algo más grave se cuestionaba para el mundo.

En 1927 se editó por unos comerciantes y unos artistas de Sitges una pequeña revista denominada L'Amic de les Arts, en la que todos los géneros de las artes impresas podían hallar acogida, en tanto que el inicial propósito era más bien modesto: dar publicidad a un variado conjunto de negocios de la costa catalana. El inicial objetivo editorial quizás no fuese otro que plasmar los anuncios publicitarios de algunos de esos comerciantes, industriales y hosteleros de esa parte de la costa española, pero para ello se acompañaron de varios artistas entre los que se encontraba el hijo de un notario de Figueras.

\section{1 salvador dalí: su perspectiva del problema}

Salvador Dalí, por aquel entonces con veinticuatro años de edad, había concluido o desistido de su formación no universitaria, recibida durante su estancia en la Residencia de Estudiantes de Madrid. Pero el pintor checoeslovaco -tal y como fue conocido inicialmente por sus compañeros de la Residencia ${ }^{31}$-, no sólo no era de esa nacionalidad, sino que era también escritor y, al reproducirse algunas de sus creaciones pictóricas, vio publicadas en esa pequeña revista las fotografías, probablemente de las primeras que hubo, de sus cuadros. Eso le debió de causar alguna impresión y escribió un artículo, muy sentido, sobre el valor artístico de la fotografía y sobre sus posibilidades para el trabajo -antes espiritual que artístico, he ahí la idea- de un no artista, es decir, un no corrupto, un no putrefacto, pues así es como él y sus amigos de por aquel entonces, Federico García Lorca y Luis

31 BUÑUEL, Luis. Mi último suspiro Barcelona Plaza y Janés, 1982. Pág. 74. 
Buñuel, se presentaban al mundo. "La fotografía pura creació de l’esperit", incluía estas expresivas afirmaciones:

¡Noves possibilitats orgàniques de la fotografía [...]

¡Fantasía fotográfica; més agil i rápida en troballes que els tèrbols procesos subconsciens! [...]

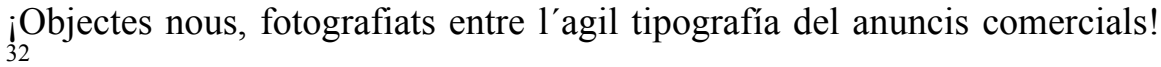

Según Dalí, la nueva manera de creación espiritual que era la fotografía estaba dotada de todas las fases de la producción del hecho poético en su justo lugar. El milagro, añadía, se produce con la misma exactitud con el que se producen las operaciones bancarias y comerciales de las que su padre daba fe escrita en su notaría $^{33}$, al hacer constar, mediante un aburrido proceso de escritura casi automática, algunos actos de los comerciantes, industriales y hosteleros que acaso fuesen los mismos que se anunciaban en L 'Amic de les Arts. Pero el espiritismo, lo espiritual, era para él otra cosa y, llegado a este punto de su discurso, añade unos puntos suspensivos que dejan en manos del lector la precisión de qué sea lo espiritual -en catalán l'espiritisme-, a continuación, remite al lector a unas determinadas obras del pasado, a las que había tenido acceso en Madrid: Vermeer de Delft fou encara altra cosa. Els seus ulls són, en la história del mirar, el cas de máxima probitat. Amb totes les tentacions, peró, de la llum. Van der Meer, nou sant Antoni, conserva intacte l'objecte amb una inspiració tota fotográfica, producte del seu humil i apassionat sentit del tacte. [...] El cristal fotogràfic pot acariciar les fredes morbideses dels blancs lavabos; seguir les lentitudes ensopides dels aquariums; analitzar les més subtils articulacions dels aparells eléctrics amb tota la irreal exactitud de la seva màgia. En pintura, per contra, si es vol pintar una medusa, és absolutament necessari de representar una guitarra o un arlequí que toca el clarinet ${ }^{34}$

Este artículo se incorporó al número 18 de L'Amic de les Arts, que apareció en octubre de 1927. Pero será en el número 31, en el último número de la revista, que apareció en abril de 1929, en el que se mencione expresamente, en una especie de

32 DALÍ, Salvador "La fotografía pura creació de l’esperit". En L 'Amic de les Arts Sitges núm. 18 septiembre 1927. Pag. 90-91.

33 BUÑUEL, Luis. Mi último suspiro Op. cit. Pág. 113. "La notaría del padre de Dalí estaba en la planta baja y la familia (el padre, la tía y la hermana, Ana María) vivían en el primer piso".

34 DALÍ, Salvador “La fotografía pura creació de l’esperit”. Op. cit. Pag. 90-91. 
declaración editorial de una revista muy transformada, la palabra que ahora nos interesa:

Una tendencia violentament anti-artistica resta definida en l'impuls exacerbat vers el documental -(la existencia i la recerca amb igual necessitat del text o producció superrealista)i el documental minuciós, prova una vegada més, l’osmosi constant establerta entre la realitat entre la realitat i la superrealitat. El documental, però, igual que les altres tendéncies anti-artistiques, està en un estat d'embrió que no priva, peró, que ja s'hagin posat avui importants problemas en extrem delicats, tal como per exemple, el dels limits i possibilitats de la documental literaria en relaciò amb la documental cinemática. De momento, però, l’impuls que ja produit influències decisives, ha estat recollit infament, artisticament, pel film de a'vanguarda. ${ }^{35}$

De lo espiritual de hacía un año y medio se pasa por tanto a unas nuevas palabras, la realidad y la superrealidad, y surge la que ahora nos ocupa. Todo ello produce en el joven escritor que se intuya el planteamiento de cuáles sean los límites entre lo documental literario y lo documental cinematográfico, fotográfico o fonográfico. Materia compleja que le conduce, en primer lugar, a la nueva forma de mirar que se dio en el siglo XVII, pues para él ese era el ejemplo máximo de ruptura estética derivada de nuevos ingenios mecánicos y ópticos, aunque dicho ejemplo lo asimilara de una manera consciente o inconsciente, como una perspectiva plenamente integrada en los museos y, en definitiva, en la cultura oficial. Vermeer de Delft -o, en España, Velázquez- representaban para él una nueva manera de mirar que triunfa y así le llega a través de los museos o de las láminas de los fotograbados editados por la industria editorial del momento. Todos los demás artistas contemporáneos del joven pintor y de sus amigos eran, sin embargo, putrefactos o corruptos ${ }^{36}$. Ignorantes de sí mismos que no acertaban a percibir la realidad a través de lo nuevo, que está a su alcance ya desde hace tiempo: la fotografía, el inconsciente o lo intuitivo o el cine y el fonógrafo.

En segundo lugar, Dalí plantea la contraposición entre la literatura -es decir, el mundo de lo escrito, de la letra-, y de la imagen -es decir, el mundo visual- que

${ }^{35}$ DALÍ, Salvador “Documentals”. En L`Amic de les Arts Sitges núm. 31 abril 1929: Pág. 10.

36 SANTOS TORROELlA, Rafael "Los Putrefactos" de Dali y Lorca. Historia y antología de un libro que no pudo ser. Madrid Publicaciones de la Residencia de Estudiantes, 1998. Pág. 100 "Primera felicitación de Dalí a Picasso. Putrefacto, putrefacto, putrefacto / acuérdate de tus pecados / ¡Oh misericordísimo Picasso! / Mira pues sus bigotes lacerados / sus botes de botones y de risas / (cien años de indulgencia)". 
rivalizaban y amenazaban la estabilidad -ahora ya denominada en neologismo griego "psicológica" - del ser humano urbano occidental. A esta idea quizás tuviera acceso el aún no famoso pintor mediante la inevitable duda reflexiva que hubo de producirse en su mente con relación a la profesión de su padre: un notario que daba fe pública en su propia casa de textos jurídicos para sus clientes. Salvador Dalí, notario (por tanto, gran memorizador), padre del que luego fuera conocido pintor, no hubiera dudado ni un instante en entregar a su hijo a la anulación más absoluta de lo lúdico que pudiera haber en su personalidad mediante el estudio literal de los textos legales creados por juristas e historiadores como Cánovas y Alonso Martínez, a pesar, como hemos visto, de que no se indicase con precisión en las leyes fundamentales del reino, en las leyes del padre -el Gran Memorizador- qué fuese en sí un documento. Esta indefinición alcanzaba a España, a Inglaterra, y a toda Europa y América. Salvador Dalí hijo acaso intuyó que algo relevante ocurría en relación a ese probable destino familiar y decidió seguir otro camino, otro método, aplicando la duda denominada paranoico-crítica (o más popularmente, "piensa mal y acertarás") por lo que se comportará respecto a su realidad circundante como un eficaz notario de su propia percepción no manipulada. Se transformó así en un contradictorio irresponsable/hiperresponsable o, si se quiere, en un meticuloso fedatario de sí mismo y su inconsciente.

Pero antes se condujo como escritor -y esto es lo que atañe al presente tema- a una nueva forma de mirar y leer las imágenes que se dio en Velázquez y en los pintores holandeses del siglo XVII y en sus escritores, embarcados en una empresa colectiva: la independencia política y económica de su señor natural, que no era el rey de España, sino su rey, aunque se diese el caso de que fuese el rey de otros diversos dominios localizados en el sur de Europa. Y utilizó en relación a ello, como hemos visto, un vocablo que por su ambiente familiar le resultaba común, aunque fuese un término (documento o documental) que también comenzaba a ser utilizado fuera de las notarías, los juzgados o los ministerios. Pero eso no aumentó la claridad en relación a la palabra sino que, por el contrario, aumentó más aún la confusión y la polisemia pues, como veremos, en su nuevo radio de acción (el reino de las artes) tampoco se tenía muy claro qué se quisiese significar o qué se refiriese con la prestigiosa locución, como se publicó en el Boletín de la Asociación de Fotografía de Cataluña: "Sin que hasta la fecha nadie haya dicho en dónde empieza la parte artística y acabe la documental. Vemos pues que el problema terminológico no está todavía resuelto pero sí vigente." 37

37 INSENSER, Elisabet. La fotografía en España en el periodo de entreguerras (19141939) Op. cit. Citando a Juan Cubano 1929: 92-93. 


\subsection{Federico García Lorca y T.S. Eliot: perspectiva del problema.}

Todos tenemos una capacidad de San Sebastián bajo la murmuración y la crítica. A San Sebastián le dieron martirio con toda razón y estuvo dentro del orden y la ley de su momento. Pecaba contra su época. [...] ipero no lo sabía! [...] Ningún mártir lo supo. Y todos lo fueron por razón de Estado. No los mataron por adorar a su Dios sino por no respetar al Dios de los demás. Todos estaban fuera de la ley. Y no tenían razón. Sócrates puesto en este aprieto quizás hubiera optado por respetar las leyes de la república. ¡Dramático conflicto! ${ }^{38}$

Poco antes de que Dalí publicase sus intuiciones críticas acerca del futuro de lo documental fotográfico y cinematográfico Lorca había remitido al pintor catalán un poema que había fechado en Lanjarón (Granada) en 1926. El romance "Reyerta de gitanos" resultó así incluido en el número de L'Amic de les Arts que se publicó en junio de 1927, y sobre la obra de Lorca se imprimió el dibujo titulado "El poeta en la Platja d'Empuries vist per Salvador Dalí". Las relaciones entre ambos eran buenas en ese monento y el poeta andaluz, a su vez, incluyó como subtítulo del poema una dedicatoria: "A mis amigos de L'Amic de les Arts" ${ }^{39}$ que no hacía presagiar ningún tipo de ruptura entre ellos.

La dedicatoria de Lorca y la entrega de este poema para su publicación y no cualquier otro quizás no haya de ser interpretada como azarosa, en tanto que se estaba incubando entre ambos, y en el ambiente crítico y creativo de la época, el valor y el carácter, la fuerza y la intuitiva revelación de lo documental para todas las $\operatorname{artes}^{40}$. Las discusiones entre ambos y Buñuel, entre otros factores, generaron la

38 SANTOS TORROELLA, Rafael "Los Putrefactos" de Dali y Lorca. Historia y antología de un libro que no pudo ser. Op cit. Pág. 61. Carta de Federico García Lorca a Salvador Dalí (Lanjarón, agosto de 1927)

39 La primera edición del poema, no obstante, no fue la de L 'Amic de les Arts puesto que ya había aparecido en 1926, en Verso y prosa. Boletín de la nueva literatura (suplemento literario del diario La Verdad de Murcia). Después fue incluido en el Primer Romancero Gitano (1924-1927) y en la edición de 1928 por Revista de Occidente pero con otra dedicatoria, a Rafael Méndez que sustituye, significativamente, a la dedicatoria que había realizado el año anterior a sus amigos catalanes.

40 SANTOS TORROELlA, Rafael "Los Putrefactos" de Dali y Lorca. Historia y antología de un libro que no pudo ser. Op cit. Pág. 59. "Varios putrefactos, 1927, junio. [...] En la carta, como en sus conversaciones, era tema constante el de la contraposición entre el pasado y la modernidad, entusiasta de ésta Salvador, y nostálgico de aquél García Lorca. La tesis del primero es la de que "ninguna época -según le escribe a su amigo- había conocido la perfección como la nuestra, hasta el invento de las Máquinas no había habido cosas perfectas, y el hombre no había visto nunca nada tan bello ni poético como un motor niquelado". 
publicación de los ya vistos artículos de Dalí, uno inmediatamente posterior -en octubre de 1927- y el otro en la última página del último número, ya en abril de 1929, acompañando una entrevista con Luis Buñuel. Las ideas que cristalizaron en esos textos debieron de mover igualmente a Lorca y a su aportación a la revista, pero acaso desde una perspectiva diferente: la del hombre de letras, el literato en el sentido más clásico de la palabra -el previo a la Ilustración ${ }^{41}$-, aunque él también se percibiese a sí mismo como un creador integrado en la vanguardia ${ }^{42}$. La forma de percibirse a sí mismo del escritor granadino, sin embargo, no resultó compartida, en lo esencial, por sus amigos, que quizás le tuvieran presente en $U n$ perro andaluz, como el título posiblemente sugiere.

Entre 1924 y el viaje a Nueva York de Lorca en 1929 el poeta intentaba aunar los recursos creativos de los poetas del Siglo de Oro con las novedades expresivas que generaban los nuevos cauces de comunicación. El verso libre y la rima asonante alternaban así con los temas y los recursos, sobre todo metafóricos y alegóricos de la mejor tradición poética española. Pero fracasó en el intento de ser tenido por vanguardista entre sus compañeros de la Residencia que no sólo estaban a la última de lo fotográfico o lo cinematográfico, sino que utilizaban esos medios eficazmente, y eso le causó gran dolor. Los creadores plásticos a los que, ciertamente, les unía una gran amistad no le tenían como uno de los suyos en lo que respecta al terreno de la innovación creativa por ser, si se quiere, un hombre de letras o, si se prefiere, tradicional. Quizás por ser sólo escritor, antes que pintor, escultor, o director de cine, o al menos fotógrafo ("La nova manera de creació espiritual que és la fotografía, posa totes les fases del fet poètic en el seu just pla"). La falta de armonía creativa y crítica con sus amigos -junto a muchas otras circunstancias personales que no trataremos-, le exigió alejamiento para adquirir perspectiva respecto a un tema importante aunque no fuese el único motor de su existencia: la captación de la realidad $-\mathrm{o}$, si se quiere ya, de lo documental- en

41 GARCÍA LORCA, Federico Obras completas. Madrid Aguilar, 1971. Pág. 96. "Las nanas infantiles (conferencia) [...] Al hablar incidentalmente de las hadas cumplí con mi deber de propagandista del sentido poético, hoy casi perdido por culpa de los literatos y los intelectuales, que han esgrimido contra él las armas humanas y poderosas de la ironía y del análisis."

42 GARCÍA LORCA, Federico Obras completas. Op. cit. Pág. 124-125. "Banquete de presentación de la nueva revista literaria Gallo, en la Venta Eritaña, el 9 de marzo de 1928 [...] Un grupo de Granada, unido al antiguo, se reúne en torno de este gallo, y creo que ahora va de firme. Todos a una. Con el amor a Granada, pero con el pensamiento en Europa. Sólo así podremos arrancar los más ocultos y finos tesoros indígenas. Revista de Granada, para fuera de Granada, revista que recoja el latido de todas partes para saber mejor cual fue el suyo propio: revista alegre, viva, antilocalista, antiprovinciana, del mundo, como lo es Granada [...] Hay que proteger esta revista, queridos amigos, porque es la voz más pura de Granada; la voz de su juventud, que mira al mundo, y desde luego, la única que se oirá fuera. Protegedla, proteged las ediciones de sus clásicos y haced posible una unión con nuestros grandes poetas del siglo XVII y los escritores de hoy, a quienes amamos y respetamos como maestros de forma y contenido". 
relación a la fuente de lo creativo y el origen o fundamento de la revelación al mundo de la verdad de las cosas y de los hechos de los seres humanos para saber más y para hacer saber más a los demás.

Tu San Sebastián de mármol se opone al mío de carne que muere en todos los momentos, y así tiene que ser. Si mi San Sebastián fuera demasiado plástico yo no sería un poeta lírico sino un escultor (no pintor). Creo que no tengo que explicarte por qué no sería pintor. Pero la distinción es sutil. Pero lo que a mí me conmueve de San Sebastián es su serenidad en medio de la desgracia, y hay que hacer constar que la desgracia es siempre barroca; me conmueve su gracia en medio de la tortura, y esa carencia absoluta de resignación que ostenta en su rostro helénico, porque no es un resignado sino un triunfador, un triunfador lleno de elegancia y de tonos grises, como un remero constante que desconociese los paseos de la ciudad. ${ }^{43}$

Uno de los resultados de esa disputa creativa y crítica con Dalí y con Buñuel fue, a mi juicio, que al incluir en el libro que gestó en su viaje americano el relato poetizado de otra muerte violenta - un homicidio, al fin y al cabo, como el que sucediera en "Reyerta de gitanos"-, se valió de procedimientos totalmente diferentes. Divergentes, al menos, respecto a los que utilizó en el Romancero gitano y en ese brillante poema que entregó a Dalí para su publicación en L 'Amic de les Arts.

Hay un elemento en "Reyerta de gitanos" que busca dar certeza, verosimilitud, a la acción que narra el poema. Al producirse la muerte de Juan Antonio de Montilla, que ha rodado muerto la pendiente, aparece un transcriptor del suceso cuya presencia quizás ofrece alguna seguridad al lector respecto a que lo sucedido sea tenido por cierto: "El juez con guardia civil / por los olivares viene" pues, a continuación, se presta una impersonal declaración: "Aquí pasó lo de siempre. / Han muerto cuatro romanos / y cinco cartagineses." La persona que habla sólo es identificada por los versos que le dan entrada en la escena poética como "Sangre resbalada gime / muda canción de serpiente."

Las palabras del anónimo testigo adquieren certeza para el lector del texto, en tanto que, sin decirlo, son transcritas por alguien ajeno a la acción que ocurre dentro del poema, de manera tan imperceptible que ni se le menciona (¿Un testigo? ¿un delator? ¿un rumor general? ¿un romance oral ya transcrito?) No es un fotógrafo, ni es un cámara de cine, ni el redactor último del poema, el autor. Es más bien un escribano, un secretario, que no es apenas apreciado o echado de

43 SANTOS TORROELlA, Rafael "Los Putrefactos" de Dali y Lorca. Historia y antología de un libro que no pudo ser. Op cit. Pág. 60. Carta de Federico García Lorca a Salvador Dalí (Lanjarón, agosto de 1927) 
menos en el texto, aunque, de algún modo se halle presente en él. La narración bebe en las fuentes del romance, cierto, pero es más que un épico romance popular pues la certeza o verosimilitud de la acción para el lector de la ciudad se adquiere sobre todo, no por una narración oral rimada -como efectivamente ocurriría en un romance- sino con la casi imperceptible presencia del escribano que recoge algunas palabras que han sido pronunciadas ante él, a preguntas del juez, del investigador del crimen cometido. En algún momento hubieron de ser transcritas, objetivamente, de su puño y letra, al llegar al barranco y al hallar la comitiva el cuerpo de Juan Antonio el de Montilla. Esas palabras son traídas de la boca de un testigo, de un espectador, un oyente, hasta un nuevo texto: el poema que, en este caso, con verso libre quiere ser actual y vanguardista en la segunda decena del siglo XX. El recurso, sin embargo, está traído del Siglo de Oro español. Eso era lo moderno, lo actual, lo técnicamente superior de esa otra época: la fidelidad a lo objetivo de los escribanos del rey en las organizaciones institucionales del XVI y XVII europeo, que dieran impulso a la existencia de organizaciones jerárquicas más complejas respecto a las hasta entonces existentes. Era importante llevar al papel las distantes acciones acontecidas en el mundo que fueran de interés para el hombre de la ciudad: el burócrata, el cortesano, para que pudieran éstos adquirir conocimiento de lo que pudiera saberse en relación a hechos de su interés. Ese factor es el que permite considerar el hecho o la acción que fuere, juzgarla y dirigirla, según fuese el caso. El Consejo, el Rey... o el cómodo lector del poema, como buen cortesano, no han tenido que trasladarse hasta la mitad del barranco para ver las navajas del crimen. Ni en el siglo XVII ni en el XX -no me atrevería a asegurarlo para el XXI-. Muchos pueden así juzgar la acción -el poema en este caso-, desde su casa, desde la oficina, o desde la Corte... desde cualquier sitio con cultura escrita suficiente para apreciar el texto, sin esperar a que llegue el cómico o el invidente a contar un romance rimado o cantado que, por el contrario, se hallaba destinado tanto para letrados como para iletrados. Lorca, excelente conocedor de los escritores del XVII español, acaso pensaba que bastaría con aportar el verso libre a la estructura del romance renovado, aunando así la complejidad metafórica con el verso libre y la acción que concluye en la muerte. Quizás imaginaba que eso era lo que demandaba su tiempo como importante y novedoso, pero me atreveré a afirmar que se apartaba de su tiempo ${ }^{44}$. La época,

44 GARCÍA LORCA, Federico Obras completas. Op. cit. Pág. 139-143. "Discurso en homenaje a Lola Membrives. En el teatro de la Comedia, 16 de marzo de 1934 [...] Cuando me hablan de la decadencia del teatro, yo pienso en los millones de hombres que esperan en los campos y en los arrabales de las ciudades ver con sus ojos nuevos de asombro el idilio con ruiseñor de Romeo y Julieta, la panza llena de vino de Falstaff o el lamento de nuestro Segismundo luchando cara a cara con el cielo. No creo en la decadencia del teatro, como no creo en la decadencia de la pintura ni en la decadencia de la música [...] El teatro ha perdido su autoridad porque día tras día se ha producido un gran desequilibrio entre arte y negocio. El teatro necesita dinero, y es justo y fundamental para su vida que sea motivo de lucro; pero hasta la mitad nada más. La otra mitad es depuración, belleza, cuido, sacrificio para un fin 
parece ser que no quería ni buscaba expiación de ningún tipo sino ingenios audiovisuales, fonógrafos, cine, microscopios, hélices etc... futurismo y preparación para la guerra, como el propio poeta hubo de sufrir, y aunar a lo escrito nuevas formas de percibir la realidad, que ahora se habría de captar a través de máquinas, que generaban también, casi automáticamente, nuevas formas de contar las cosas que pasan.

Federico García Lorca, no obstante, no se dejó acomplejar por dos amigos dotados del último modelo de cámara de fotografías o de una cámara de cine $\mathrm{y}$ puso distancia y tierra de por medio para adquirir la perspectiva necesaria en su contestación. En el siguiente golpe no fallaría y planteó que sólo la gente muy simple necesita de una cámara de fotos para hacer una fotografía o de una cámara de cine para hacer una película:

El año de 1917 tuve la suerte de ver un hada en la habitación de un niño pequeño, primo mío. Fue una centésima de segundo, pero la vi. Es decir, la vi [...] como se ven las cosas puras, situadas al margen de la circulación de la sangre, con el rabillo del ojo, como el gran poeta Juan Ramón Jiménez vio las sirenas, a su vuelta de América: las vio que se acababan de hundir. Esta hada estaba encaramada en la cortina, relumbrante como si estuviera vestida con un traje de ojo de perdiz, pero me es imposible recordar su tamaño ni su gesto. Nada más fácil para mí que inventármela, pero sería un engaño poético de primer orden, nunca una creación poética, y yo no quiero engañar a nadie. No habló con humor ni con ironía, hablo con la fe arraigada que solamente tienen el poeta, el niño y el tonto puro. ${ }^{45}$

Una nueva muerte -tan familiar como tema para él- surgió en, al menos, uno de sus nuevos poemas y no precisó ya de un escribano, ni de un juez para ser tenida por cierta. Obviamente el lector puede leer un poema como quiera, pero en el poema "Asesinato (dos voces de madrugada en Riverside Drive)" el autor subtituló la breve composición, de tal manera que no hay muchas opciones porque sólo son dos voces las que han de oírse. Podría pensarse en otras posibilidades, pero el autor ha indicado dos voces. Se trata de dos voces que se oyen en un lugar llamado Riverside Drive y, sin embargo, parece haber más voces deshilvanadas. Las dos

superior de emoción y cultura. No estoy hablando del teatro de arte, ni de teatro de experimentación porque este tiene que ser de pérdidas exclusivamente y no de ganancias, hablo del teatro corriente, del de todos los días, del teatro de taquilla, al que hay que exigirle un mínimo de decoro y recordarle en todo momento su función artística, su función educativa. El público no tiene la culpa; al público se le atrae, se le engaña, se le educa y se le da, sin que él se dé cuenta, no gato por liebre, sino oro por liebre. Pero sin perder de vista que el teatro es superior al público y no inferior, como ocurre con lamentable frecuencia".

45 GARCÍA LORCA, Federico Obras completas Op. cit. Pág. 96. "Las nanas infantiles (conferencia)" 
voces pueden ser identificadas con los guiones que les dan entrada en el texto y aisladas. Las dos voces con guiones dicen lo siguiente:

- Una grieta en la mejilla.

- ¿Cómo, cómo fue?

- Así.

- ¡Déjame! ¿De esa manera?

- Sí.

- ¡Ay, ay de mí!

Se trata de una breve y agitada conversación entre dos personas alarmadas por un hecho que no se expresa en el diálogo, aunque quizás ya lo conocemos por el título: "Asesinato (dos voces de madrugada en Riverside Drive)". De esta manera, el lector se halla situado dentro del marco circunscrito: dos voces en Riverside Drive. Cada cual puede imaginarlas como prefiera, en relación a quien quiera, pues no hay otra indicación pero también se ha de considerar la presencia del resto del poema, intertextualizado entre esos versos:

¿Cómo fue?

¡Eso es todo!

Un alfiler que busca

Una uña que aprieta el tallo.

hasta encontrar las raicillas del grito.

Y el mar deja de moverse.

El corazón salió solo. ${ }^{46}$

Se trata de la voz de un narrador, no tiene guiones, pero no está integrada en el texto como una nueva y tercera voz que se relacione con los personajes que pasean por Riverside Drive. Sólo se cruzan con el lector. Se trata, por ello, de una fuente de información destinada al lector, no se oye entre los fugaces personajes, es ajena al diálogo pues semeja la representación poetizada de los carteles de una película cinematográfica. La técnica narrativa respecto a "Reyerta de gitanos", por lo tanto, ha cambiado radicalmente porque no hay escribano alguno dentro del texto que dé verosimilitud al suceso. Es decir, dentro del poema hay una cámara de cine.

Un lector culto del Siglo de Oro podría entender "Reyerta de gitanos", pero quizás no interpretaría bien "Asesinato (dos voces de madrugada en Riverside Drive)" porque para entender este poema puede que sea necesario haber visto cine. Quizás ese lector del siglo XVII podría pensar en una abstracción gongorina, pero no lo es: es sólo un breve guión de una película y cada cual puede imaginarla, visualizarla o dirigirla, como quiera, aunque acaso sea preciso haber ido algunas veces al cine. El procedimiento, la técnica mediante la que se percibe como cierta y verosímil la acción no es, por tanto, un proceso, una declaración judicial, un texto intertextualizado dentro de otro texto, sino una cámara, una caja oráculo, que opera como poderoso transcriptor de un hecho, que puede incluso que no sea ni un

${ }^{46}$ GARCÍA LORCA, Federico Obras completas Op. cit. Pág. 490-491 Poeta en Nueva York (1929-1931) 
asesinato. Ese acaso es un señuelo que utiliza Lorca en el título, quizás como un inconsciente prestidigitador que llamase la atención, pero lo que se hace presente es que se trata de una breve conversación, que ciertamente puede tratar sobre un asesinato, en la rivera de un río, la cual es captada por una cámara, ante la que secuencialmente se enfocan unos carteles con unos textos. El poder de transcribir, de dar certeza al hecho narrado -de documentar el hecho-, ya no se halla en otro escritor intertextualizado -el omniscente escribano cervantino-, sino que se deriva de una cámara cinematográfica: con este pequeño guión cada cual imaginaría, o rodaría, una película diferente, igual que cada cual interpretaría los textos guionizados de una manera diferente a la de cualquier otro lector. Lo objetivo, por un lado, cierra caminos, por otro lado nos abre otros diferentes.

Al regresar a España desde América percibirá ese cambio no sólo en el mundo sino en sus propios maestros o principales referentes: los poetas del Siglo de Oro, Góngora o Lope. Y les puede dotar así de otra perspectiva crítica en la que ya no se hallan presentes sólo los romances transformados, novedosamente contextualizados para el cortesano y el público de la incipiente gran ciudad. Por algo se ha calificado recientemente a la poesía de Góngora como de "cine rústico" 47 . Apreciará ya la presencia de ingenios mecánicos que también son capaces de enlazar su época con la de sus maestros y atribuye a éstos una variante en la forma de hacer ciertos y verdaderos sus poemas para el lector de aquel tiempo; ya se verán involucrados -como en algunos otros poemas del momento-, instrumentos, artefactos o ingenios (el microscopio o la cámara fotográfica) cuyos alquímicos orígenes se hallan en el siglo XVII y finales del XVI:

Y cansado de castellanos y de "color local", leía su Virgilio con una fruición de hombre sediento de elegancia. Su sensibilidad le puso un microscopio en las pupilas. Vio el idioma castellano lleno de cojeras y de claros, y con su instinto estético fragante empezó a construir una nueva torre de gemas y piedras inventadas que irritó el orgullo de los castellanos en sus palacios de adobes [...] Amaba la belleza objetiva, la belleza pura e inútil, exenta de congojas comunicables [...] Naturalmente, Góngora no crea sus imágenes sobre la misma Naturaleza, sino que lleva el objeto, cosa o acto a la cámara oscura de su cerebro y de allí salen transformados para dar el gran salto sobre el otro mundo con que se funden. Por eso su poesía, como no es directa, es imposible de leer ante los objetos de que habla. Los chopos,

47 CARMONA, Ángeles Góngora Ya (z) Toledo Consejería de Cultura, Turismo y Artesanía de Castilla-La Mancha, 2009. Pág. 31. 
rosas, zagales, y mares del espiritual cordobés son creados y nuevos. ${ }^{48}$

Francisco de Quevedo era el poeta nacional por excelencia, tal y como John Milton lo era para la crítica en lengua inglesa y en ambas tradiciones literarias se seguía la pauta marcada desde el XIX. Las grandes figuras de ambos escritores eclipsaban a otros poetas del XVII, pero en el ámbito anglosajón comenzó a perfilarse la figura de T.S. Eliot, no sólo como el poeta que había publicado The Waste Land en 1922, sino como el crítico que reivindicaba a Andrew Marvell o a John Donne. Lorca y Eliot fueron protagonistas de ese cambio, como integrantes de las generaciones o escuelas de sus respectivos universos literarios. Ambos coincidieron por separado en el distanciamiento de los dos poetas más representativos de sus respectivas tradiciones, acaso como reflejo del fin de una época que concluía con las guerras mundiales del siglo XX. Dicha coincidencia, sin embargo, adoptaba formas muy diferentes en cada uno de sus ámbitos culturales pues Lorca y sus compañeros del 27 no hubieron de renegar expresamente de generaciones anteriores ni tampoco de otros escritores del XVII no atacaron frontalmente, por tanto, la poesía de Quevedo o la de Antonio Machado-, sino que les bastó con reivindicar a Góngora y con ser ellos mismos en todo lo cual ya iba comprendido el distanciamiento del poeta conceptista madrileño por contraste con el poeta cordobés.

T.S. Eliot y sus seguidores no tenían el trabajo crítico tan elaborado en el siglo en el que buscaban parte de las raíces de su propio tiempo y tuvieron que desmarcarse más expresamente de la gran influencia que John Milton ejercía dentro de su literatura ${ }^{49}$. Las teorías críticas del expatriado norteamericano, en algunos aspectos, quizás recuerden al culteranismo de Góngora, pero ese factor no se desprende directamente del siglo XVII británico, mientras que la dialéctica que enfrenta al culteranismo y al conceptismo hunde sus raíces en los propios poetas y comentaristas del Siglo de Oro ${ }^{50}$. Según Eliot, el poema se ha de constituir en una

48 GARCÍA LORCA, Federico Obras completas Op. cit. Pág. 67 y 73. "La imagen poética de Góngora (conferencia)"

${ }^{49}$ Marvell, pongamos por caso, no era enemigo de Milton, sino su protegido y también su amigo personal, no fue el creador de una escuela crítica opuesta a la de Milton; el poeta de Hull siempre reconoció en el londinense a su maestro. La poesía de Marvell era muy diferente a la de Milton, pero no existió entre ellos la inquina ni la rivalidad social que existió entre los poetas españoles.

50 GARCÍA LORCA, Federico Obras completas Op. cit. Pág. 77 y 78. "La imagen poética de Góngora (conferencia) [...] Es un problema de comprensión. A Góngora no hay que leerlo, sino estudiarlo. Góngora no viene a buscarnos, como otros poetas, para ponernos melancólicos, sino que hay que perseguirlo razonablemente. A Góngora no se le puede entender de ninguna manera en la primera lectura. Una obra filosófica puede ser entendida por unos pocos nada más, y, sin embargo, nadie tacha de oscuro al autor. Pero no, esto no se estila en el orden poético, según parece". 
ocasión para el estudio y para la puesta en práctica de la imaginación por lo que su valor deriva de su misma dificultad, convirtiéndose en una suerte de texto sacro, una especie de documento tan moderno como críptico, que se ha de trabajar en el aula antes que en otro lugar ${ }^{51}$. La complejidad de la vida en una sociedad industrializada impedía seguir la inercia del XIX en esta materia, pues si la realidad se manifestaba como extremadamente compleja también la poesía habría de serlo.

Lorca y el propio Eliot pueden así ser percibidos como una parte de la tradición -la propia de la literatura española o la de la inglesa antes que la occidental, si se quiere- dentro de la idea crítica de T.S Eliot, aunque la palabra "tradición" no adquiriese en España el sentido institucional que se aceptó en entreguerras para la literatura británica ${ }^{52}$. Elitismo y cultura popular conviven, tanto en Lorca como en

La materia sigue siendo conflictiva, aun hoy en día. Sobre esta misma cita de Lorca y sobre la dificultosa actualización de la poesía de Góngora puede expresarse igualmente lo siguiente: "Y si por entender se entiende la comprensión significativa diría que nos preocupamos en exceso por ella y nos olvidamos de que lo que tenemos entre manos es poesía, es decir, un combinado de palabra, música e imagen, un cine rústico". En CARMONA, Ángeles Góngora Ya (z) Op. cit. Pág. 31.

${ }^{51}$ Las referencias integradas en The Waste Land a Paradise Lost o a otras obras clásicas, por ejemplo, son difícilmente apreciables para el lector si no se cuenta con notas o si no se consultan las obras. El título de la segunda de sus partes, pongamos por caso, es alusivo a una obra de Thomas Middleton (A Game of Chess) relativa al ajedrez político de la época la cual fue popular en Londres en los años veinte del siglo XVII. Pero ya sólo podría resultar significativa para algunos especialistas, o algunos términos y expresiones son cultismos, prácticamente indescifrables para el lector común.

52 ELIOT T.S. "Tradition and the Individual Talent" Norton Anthology of American Literature. Vol. II. Nueva York / Londres: W.W. Norton \& Company., 1985. Pag. 12731274. "Tradition is a matter of much wider significance. It cannot be inherited, and if you must obtain it by great labour. It involves a perception, in the first place, the historical sense, which we may call nearly indispensable to any one who could continue to be a poet beyond his twenty-fith year, and the historical sense compels a man to write not merely with its own generation in his bones, but with a feeling that the whole of the literature of Europe from Homer and within it the whole of the literature of his own country has a simultaneous existence and composes a simultaneous order.. This historical sense, which is the sense of the timeless and of the temporal together, is what makes a writer traditional. And it is at the same time what makes a writer most acutely conscious of his place in time, of his own contemporaneity" (1919 / 1920). Pero la misma palabra "tradición" tenía un problema para ser aceptada en España como soporte de la trayectoria literaria porque existía una opción política responsable de recientes conflictos civiles, el carlismo, que aún se identificaba y presentaba como tradicional o tradicionalista aunque la idea filosófica existiese por igual en varios autores. Por ello esa circunstancia dificultaba percibir una línea o trayectoria gradual y pacífica, una tradición única en lo interno del país y de su literatura, que se identificase con dicha palabra. El tradicionalismo, con proyección ideológica hacia el pasado y hacia la literatura nacida en el Antiguo Régimen, aún se hallaba plenamente 
Eliot, aunque esa dialéctica quizás se refleja con más claridad para ambos en los diferentes planteamientos acerca de la función social que hubiera de cumplir el teatro en la vida pública. La poesía de ambos también refleja esa dificultosa convivencia en la utilización del lenguaje cinematográfico en sus obras poéticas, integrando en la tradición poética y en la cultura escrita las nuevas formas de captar la realidad que proporcionaban los nuevos ingenios de la comunicación en una cultura de masas

\subsection{Luis Buñuel y Robert Flaherty: perspectiva del problema}

¿Qué está más cerca de tu espíritu, el film antiartístico industrial o los diversos ensayos de film-arte hasta ahora realizados? - Las ideas tradicionales de arte aplicadas a la industria me parecen monstruosas. Ya se trate de un film o de un auto. El artista es el encargado de ensuciar los más puros objetos de nuestra época. Quien los comprende menos. Y el cine europeo, salvo escasísimas excepciones, no tiene otra ocupación que la de hacer arte. Incluso el cinema ruso, que además de artístico, es literario y tendencioso. [...] ¿Te interesa el arte? - Nada, y aún menos el artista. Hallo con ventaja los sucedáneos, en las numerosas y novísimas creaciones de nuestra época. Estoy inmunizado contra el tifus. ${ }^{53}$

Poco dopo il 1930 una nuova parola ed un nome nuevo cominciarono a ricorrere con una certa regolarità su diverse pubblicazioni. La nuova parola era "documentario", il nome nuovo John Grierson. La parola "documentario", per essere precisi, era apparsa la prima volta in una ressegna redatta da Grierson per il New York Sun nel febbraio del 1926. Derivaba de quel "documentaire" que era un termine usato dai francesi per i film di viaggi. Grierson lo usò per definiré Moana di Robert Flaherty, in cui si descriveva la vita degli abitanti delle isole dei Mari del Sud. Più tardi egli defini il documentario "una elaborazioni creativa della realtá." 54

presente en la dinámica política y también estética - Las sonatas de Valle Inclán son el caso-, que desembocó en la Guerra civil.

${ }^{53}$ BUÑUEL, Luis "LUIS BUÑUEL "metteur en scène" cinematogràfic, del qual pot esperar molt el cinema europeu, i les produccions del qual aviat seran revelades al públic, ha contestat a Salvador Dalí, i per a "L`Amic de les Arts" el següent qüestionari”. En L 'Amic de les Arts Sitges núm. 31, abril 1929: Pág.16.

${ }^{54}$ HARDY, Forsyth. Documentario e realtá .Traducción de Fernaldo di Giammatteo. Roma: Bianco e Nero Editore. 1947. Pág. 19. 
Of course, Moana being virtual account of events in the daily life of a Polynesian youth and his family, has documentary value. ${ }^{55}$.

Robert Flaherty había estrenado Nanook of the North en 1922, su primera película, pero nadie la había calificado inicialmente como documento o documental. Fue en 1926, al estrenarse su segundo trabajo-Moana, sobre el rito de paso en el tatuaje polinesio-, cuando la palabra se empleó por primera vez en lengua inglesa para referirse a una película cinematográfica. ${ }^{56}$. Pero no fue el propio autor quien utilizó la palabra en ese sentido, sino, como acabamos de ver, el director británico John Grierson, el 8 de febrero de 1926, en un artículo publicado en The New York Sun bajo el seudónimo "The Moviegoer", al hacer la crítica de Moana.

Poco después, una tesis de Maurice Legendre, defendida en la Universidad de Burdeos y publicada en 1927 (Las Jurdes. Étude de géographie humaine) llamó la atención de Luis Buñuel ${ }^{57}$. El investigador llevaba desde 1910 estudiando la comarca de Las Hurdes, con numerosos viajes y trabajo de campo ("Mi archivo está en mis ojos y en mis manos") con fotografías que él mismo tomaba, por lo que su estudio fue de gran atractivo para el director de cine aragonés. Legendre era el entonces secretario del Instituto Francés de Madrid, en la aún existente Casa de Velázquez, y había realizado sus viajes a Las Hurdes con diversos acompañantes. $\mathrm{Su}$ método y su propósito redentorista quedaron expresadas en el prefacio de su investigación:

[...] Mais cette étude ne se fait pas dansun fauteuil.

Nous l'avons menée un peu comme une enterprise de chevalerie errante, et nottre premier dessein a été de travailler, pour notre modeste part, á la rédemption des Jurdanos [...].

${ }^{55}$ MURPHY William T. Robert Flaherty: a guide to references ans resources.... Citando a John Grierson en The New York Sun 8 de abril de 1926 Boston: G. K. Hall \& Co, 1978. Pág. 64.

${ }^{56}$ MURPHY William T. Robert Flaherty: a guide... Op. cit. Pág. 16 "Here for the first time in English a critic used the word "documentary" to describe a film, though the French had used it ("documentaire") in reference to film of travel and exploration." Igualmente habría que seguir el rastro de la locución en los trabajos cinematográficos de Roberto Omegna para la lengua italiana.

Las Hurdes / Tierra sin pan. Un documental de Luis Buñuel. Madrid Junta de Extremadura, 2000. Pág. 15 "Entrevista concedida por Luis Buñuel a André Bazin y Jacques Doniol-Valeroze (Cahiers de Cinema, 1954) - Yo había leído algo de Maurice Legendre, que fue director del Instituto Francés de Madrid, sobre la vida de ciertos grupos humanos atrasados. Era una tesis de 1200 páginas, un estudio muy completo y minucioso sobre ese género de vida [...] Ese libro me entusiasmó y pensé en un film”. Exageración justificada por el tiempo transcurrido entre la entrevista de 1954 y la lectura del libro de Legendre, en tanto que éste tiene 512 páginas. 
[...] nous espérons pouvoir montrer que la societé á

las Jurdes reste en marge de 1'histoire $[\ldots]^{58}$

Sus finalidades se enmarcaban dentro del catolicismo social, pero a pesar de su intención de extraer de la historia a la legendaria comarca lo cierto es que, por otra vía, volvió a integrarla en la actualidad, pues como él mismo refiere en su prefacio hay un hecho, que integra a la comarca en su tiempo: "c' est celle du roi Alphonse XIII, qui, en 1922, visité le pays et fixé sur lui, définitivement, espéronsde l'attention de l'opinion publique et des gouvernments". En el verano de 1914 Legendre también había ido hasta allí con Miguel de Unamuno y el polémico escritor publicó una pormenorizada relación de su viaje, en términos muy

58 LEGENDRE, Maurice Las Jurdes: étude de géographie humaine. Bordeaux Gounouihou, 1927. Préface. Pág. VII y X. Recientemente editada en español como LEGENDRE, Maurice Las Hurdes: estudio de geografia humana. Traducción de Enrique Barcia Mendo Introducción de Paloma Sánchez Miguélez y José Pablo Blanco Carrasco. Coda de Luciano Fernández Gómez. Mérida Junta de Extremadura, 2006. Estas dos citas y las siguientes proceden del prefacio en francés c de Legendre, las siguientes citas de su estudio las realizaremos de su reciente traducción al español:

"Si tuviéramos que elegir una fecha para indicar cuándo termina nuestro estudio, esa fecha sería la de 1922, como el año que resume las diversas fases de la integración en la historia de lo que ha sido el fenómeno hurdano" (Prefacio de Legendre. Op. cit Pág. 88). "Sin caer en el "materialismo histórico" que es el determinismo pseudo científico aplicado a las ciencias del hombre" (Prefacio de Legendre. Op. cit Pág. 90) "Es un hecho singular que la leyenda de Las Batuecas y de Las Hurdes haya sobrevivido hasta nuestros días, sobre todo si tenemos en cuenta que estos territorios se encuentran situados en plena Europa Occidental, a tan sólo algunas leguas de Salamanca, una de los grandes focos de nuestra civilización". (Prefacio de Legendre. Op. cit Pág. 95) Los prejuicios, no obstante no se hallaban lejos de su investigación, puesto que tomaba a la comarca como un referente en microcosmos de la realidad de la península: "En seguida se puso de manifiesto, a lo largo de nuestro estudio, que las singularidades de Las Hurdes eran, con mucha frecuencia, singularidades españolas. No queremos decir que esta región sea un reflejo fiel de España, pero sí un exponente caricaturesco, si quitamos a esta última palabra cualquier significado injurioso, una muestra que revela brutalmente los rasgos del conjunto y que señala, al mismo tiempo, sus defectos y sus cualidades. Estudiar este extraño país es, pues, estudiar la misma España: en él se reconoce más de una vez lo que es España, se descubre a menudo lo que ha sido y se adivina lo que habría podido ser". (Prefacio de Legendre. Op. cit. Pág. 84) Se puede afirmar que los tópicos de su propia clase social y los de su propio país, sobre lo que pudiera hallarse más allá de los Pirineos, no le abandonaron en ningún momento durante su investigación. El profesor Robert Ricard, igualmente hispanista, y acompañante de Legendre en alguno de sus viajes a la comarca, nos dejó esta semblanza de su persona: "Un hombre de espíritu dogmático y sin matices, con una gran robustez física y moral y un temperamento autoritario, un carácter rígido y casi monolítico, un católico a machamartillo incapaz de la menor tolerancia. Podía parecer un nacionalista cerrado a todo lo que no fuera la tradición de su propia patria” (Introducción de la edición de 2006, Pág. 22) 
elogiosos para la investigación ${ }^{59}$. Y la relación de dicha excursión -según el autor la denomina-, fue incluida en su libro Andanzas y visiones españolas con una primera edición en 1922, coincidente con el viaje de Alfonso XIII ${ }^{60}$, en cuya organización o, cuanto menos, inspiración, participó el propio Legendre con Gregorio Marañón. El artículo de Unamuno tuvo una segunda edición en 1929 dentro de Andanzas y visiones españolas pero la crónica ya había sido publicada también en 1914, en fechas próximas a su redacción, como artículo de prensa en La Nación de Buenos Aires y en El Imparcial de Madrid.

La tesis de Legendre le sirvió igualmente a Buñuel de inspiración para planificar el rodaje de una película que reflejara un viaje diferente a la comarca. Pero no es muy seguro, como veremos, que las palabras adaptación, inspiración o soporte hayan de ser las más adecuadas para referir lo que Buñuel tuviera en mente respecto a dicha tesis o la relación del viaje de los profesores. Buñuel, en todo caso, era también buen amigo de la hija de Legendre, Aliette, puesto que ella pertenecía a la tan nombrada "Orden de Toledo" ${ }^{61}$, que Buñuel fundó con sus amigos de la Residencia de Estudiantes.

${ }^{59}$ UNAMUNO, Miguel de. "Las Hurdes" En Andanzas y visiones españolas Madrid Aguilar, 1957. Pág. 242-243 "Mis dos compañeros eran monsieur Jacques Chevalier, profesor del Liceo de Lyon, y monsieur Maurice Legendre, este puro francés tan amante y tan buen conocedor de nuestra España. Legendre conocía ya las Hurdes. En el número de julio de este año de la España Moderna puede verse la traducción de un trabajo suyo. "El Corazón de España", publicado antes en Le Correspondant. Es algo que debe leerse en España y hacer votos por que todos nuestros amigos franceses sean como Legendre."

${ }^{60}$ LEGENDRE, Maurice Las Hurdes: estudio de geografia humana. Op. cit. Introducción de Paloma Sánchez y José Pablo Blanco Pág. 12 y 13. “[...] el trabajo de Legendre no se centra tan sólo en un objetivo académico ya que a partir de aquel primer viaje, se comprometerá el investigador en una permanente campaña para tratar de hacer llegar a la opinión pública el problema detectado en la comarca. Así, en 1914, propone a su amigo D. Miguel de Unamuno un viaje por la región hurdana que posteriormente repite cuando en abril de 1922 acompaña a la Comisión Samitaria presidida por el Dr. Gregorio Marañón. Esta agrupación planifica la histórica visita de Alfonso XIII quien, más adelante, en reconocimiento a su interés por esta ignorada comarca otorga al investigador la Cruz de la Orden de Alfonso XII".

${ }^{61}$ BUÑUEL, Luis. Mi último suspiro Op. cit. Pág. 72-73 "Volví a menudo con mis amigos de la Residencia y, el día de San José de 1923, fundé la "Orden de Toledo" de la que me nombré a mi mismo condestable. Aquella Orden funcionó y siguió admitiendo miembros hasta 1936. Pepín Bello era el secretario. Entre los fundadores estaban Lorca y su hermano Paquito, Augusto Casteno, el pintor vasco José Uzelay y una sola mujer, muy exaltada, discípula de Unamuno en Salamanca, la bibliotecaria Ernestina González. [...] Debajo, más modestos, se encontraban los escuderos, entre los que figuraban Georges Sadoul, Roger Desormières y su esposa Colett, el operador Elie Lotar, Aliette Legendre, hija del director del Instituto Francés de Madrid, el pintor Ortiz y Ana María Custodio." No es de descartar, por tanto, que Aliette no refiriese a Buñuel algún relato de su propia presencia en la comarca, puesto que ella misma acompañó a su padre en alguna ocasión en 
En ese mismo año de 1927, en el que Legendre defendía su tesis y en el que Lorca y Dalí intercambiaban su correspondencia sobre el valor de las artes, Frances Flaherty escribió un artículo en el que ella, y presumiblemente Robert Flaherty ${ }^{62}$, aceptaban la utilización de la palabra documental para las películas de Robert; y comenzó a desarrollar críticamente los principios de lo que debería ser el género documental:

It is this development, independent, or story, or start, depending on nothing but what is in the camera itself, that I suggest to you as a destiny of a screen. I suggest it as a great destiny, because pictures made from life, of the drama inherent in life, are documentary and philosophic. In them the educational, the religious and the dramatic are blanded into one. ${ }^{63}$

En 1927 Luis Buñuel estaba trabajando en la idea de una película en la cual las escenas reales se alternarían con escenas de ficción de manera indistinta, desarrollando un guión que debería haber escrito Ramón Gómez de la Serna. Pero Buñuel, como él mismo indica en sus memorias, no era un hombre de letras, aunque la literatura ejerciese sobre él una gran influencia; superior a la que ejerciese sobre Flaherty que en ocasiones incluso prefería trabajar sin guión o adaptación, fiando todo a la intuición y a la ausencia de ideas preconcebidas. Tras El perro andaluz, Buñuel intercaló en La Edad de Oro (1930) algunas secuencias de la realidad (o planos documentales) con los escenarios de ficción u oníricos. Unos años después, sin embargo, un golpe de suerte le ayudó a conseguir financiación para su proyecto hurdano, cuando el pedagogo, pintor y escultor anarquista Ramón Acín -a quien le había tocado la lotería de Navidad en

sus viajes, o al menos así se refiere en el prefacio del libro de Maurice Legendre: "Nuestra hija Aliette no temió durante una de las excursiones, afrontar los rigores del viaje, de manera que es una de las pocas francesas que han penetrado en Las Hurdes (creemos que son tres en total: las otras dos han sido la señorita Anne See y la señora Brown) [...]. (Prefacio de Legendre Op. cit Pag.91-92)

${ }^{62}$ MURPHY William T. Robert Flaherty: a guide... Op. cit. Pág. 64. "Flaherty rarely explained his films in terms of theory, nor did he intellectualize about documentary".

${ }^{63}$ MURPHY William T. Robert Flaherty: a guide... Op. cit. Pág. 65. "Frances wrote an article one year after the Grierson review of Moana, its significant was twofold. She herself, and presumably her husband, accepted and used Grierson`s documentary label. Secondly, she began to develop the documentary principle even before Grierson that drama must be discovered in the subject matter of the film [...] In 1927 the Flahertys saw Eisenstein's film Potermkin. Frances wrote in the same article that they had used the camera in a similar way "an historical incident has been re-enacted, and over these reenacted scenes that camera has been brought to play as over actual life, and the result is that same conviction of reality". 
diciembre de 1932- aportó la cantidad necesaria para llevar a cabo el rodaje ${ }^{64}$. La investigación que comenzó Legendre en 1910 inspiró así los dos viajes, por un lado el de Alfonso XIII en $1922^{65}$, y por otro el de Buñuel en 1933, que leyó su libro ya publicado, pero por vías diferentes y en contextos y con finalidades muy diferentes el uno del otro.

La idea matriz de Las Hurdes / Tierra sin pan, el pretexto para la película, se hallaba en la tesis de Legendre, quizás también en ese más lejano viaje del entonces secretario del Instituto Francés con Unamuno ${ }^{66}$, pero, el nuevo contexto era el derivado de la República española. El rodaje comenzó el 23 de abril de $1933^{67}$ y Buñuel obtuvo para rodar un permiso oficial concedido por la Dirección General de Bellas Artes y por la Dirección General de Sanidad en el que se le autorizaba "para hacer una película artística sobre Salamanca y un documental pintoresco sobre las Hurdes" ${ }^{\circ 8}$. Es decir, las palabras documento o documental con

${ }^{64}$ BUÑUEL, Luis. Mi último suspiro Op. cit. Pág. 136-137 y. SÁNCHEZ VIDAL, Agustín. "De las Hurdes a Tierra sin pan". Op. cit. Pág. 43. La cantidad, al parecer, fue de 20.000.pesetas, que posteriormente Buñuel devolvió a los hijos de los Acín al haber sido ambos muertos en la Guerra civil.

${ }_{65}$ "Creemos que alguna relación guarda con el viaje de Miguel de Unamuno, gran amigo de los doctores Marañón y Goyanes. Es muy probable que este último viaje, cuyos resultados fueron particularmente puestos de relieve por el doctor Marañón y por el diputado conde de Romilla, contribuyese en gran medida a que el rey Alfonso XIII tomara la decisión de visitar esta región desconocida (Prefacio de Legendre Op. cit Pag.91-92)

${ }^{66}$ BUÑUEL, Luis. Mi último suspiro Op. cit. Pág. 72. "Me gustaría evocar también a Unamuno, el filósofo catedrático de Salamanca. También él, al igual que Eugenio d'Ors, iba a visitarnos a menudo a Madrid, donde ocurrían tantas cosas. Fue confinado en Las Canarias por Primo de Rivera. Después lo encontré exiliado en París. Era un hombre célebre, muy serio, bastante pedante y sin pizca de humor".

67 AZAÑA DÍAZ, Manuel Diarios, 1932-1933 "Los cuadernos robados" Barcelona Edit Crítica, 1997. La difícil situación política puede percibirse, en todo caso, en la entrada para ese día del diario del propio Presidente de Gobierno, documento escrito necesario para conocer la época: " 23 de abril Salgo del despacho muy tarde, porque es domingo. Hablo de cosas indiferentes con Saravia y Menéndez, hasta la hora de comer. Casares me dice por teléfono que tiene noticias de que en un pueblo de Badajoz hay un tumulto y está herido un guardia civil. ¡Fastidioso! Después de comer, voy con Lola y Cipriano a Navacerrada. Todavía hay mucha nieve. La carretera del Puerto de los Cotos está borrada. Mucha gente patina. Soldaditos en el Centro de Montaña. Frío. Volvemos por Manzanares. Tenemos que ir a la embajada de Portugal, y, en efecto, vamos. La flor y nata de la diplomacia. Estoy poco tiempo. Regreso al ministerio. Casares me comunica que en Hormechos hay cuatro muertos. En el resto de España sin novedad. Los primeros datos electorales, denotan avance de las derechas y de los socialistas".

${ }^{68}$ SÁNCHEZ VIDAL, Agustín. "De las Hurdes a Tierra sin pan”. Op. cit. Pág. 43 y HERRERA NAVARRO, Javier. "Pretexto, contexto e hipertexto en Las Hurdes/Tierra sin pan". Op. cit.. Pág. 35 En la nota 30 a este trabajo se especifica que los permisos fueron "Concedidos por Pascua, Director General de Sanidad, y Ricardo Orueta, Director General de Bellas Artes". 
independencia, y también con fundamento, en las ideas críticas de los especialistas, ya se hallaban asentadas en la organización institucional española y se utilizaban en el lenguaje oficial para referirse a trabajos cinematográficos pintorescos, así como para clasificar y autorizar o prohibir las películas que perteneciesen a dicho género.

La percepción de lo documental cinematográfico en Inglaterra quizás no fuese muy diferente, aunque los objetivos políticos que se persiguiesen por gobierno y administración fuesen diferentes a los objetivos pedagógicos de Gregorio Marañón. En 1932 John Grierson había accedido a contratar a Robert Flaherty para trabajar para el organismo del Imperio británico en el que el director inglés era responsable de su unidad fílmica institucional: the Empire Marketing Board ${ }^{69}$, pero el director norteamericano no fue contratado como profesor. Su tarea consistió en rodar intuitivos planos sobre la esforzada vida de los empleados de la industria británica $^{70}$, y después esos planos serían reinterpretados y montados por el propagandista Grierson y su equipo de colaboradores: "men must accept the environment in which the live, with its smoke and its steel, even with its rain" 71.

69 MURPHY William T. Robert Flaherty: a guide... Op. cit. Pág. 21. "From Germany Flaherty went to England which served as his base of operations for almost the entire decade of the 1030s [...] It was Frances Flaherty who telephoned John Grierson from Berlin soliciting a job for her husband. As head of the film an enthusiastic supporter of Flaherty's work. Grierson recognized his chance to elevate the stature of his film unit. The Empire Marketing Board was charged with making productions to promote British industry".

70 MURPHY William T. Robert Flaherty: a guide... Op. cit. Pág. 21. "Some difficult emerged over Flaherty's characteristic refusal to write a script. Grierson needed one to satisfy the demands of government officials. [...] When Grierson threatened to withhold money if no script was forthcoming, Flaherty sequestered himself in a hotel for three days. He then emerged with a wad of paper. The top sheet, written in a heavy hand said: "INDUSTRIAL BRITAIN" A film about Craftsmen, by Robert Flaherty." The other pages were completely blank.

71 MURPHY William T. Robert Flaherty: a guide... Op. cit. Pág. 82-83. "Grierson shared Flaherty's sense of discovery [...] The camera could see more intimately that the human eye. Grierson and Flaherty shared the same mystical faith of the motion picture camera to reveal reality [...] Flaherty created a film language, Grierson seemed to say [...] that language needed only to be applied to English life [...] Grierson asked that greater attention be to everyday life in England rather than the exotica for which English writers and filmmakers were famous [...] Grierson recognized Flaherty's work as exceptional, but he did not exactly persuade others to follow in Flaherty's inimitable footsteps near the far corners of civilization [...] Differences in philosophy were of course significant. Grierson cast much doubt on the ability of the heroic individual to trascent the economic forces that governed his life [...] preferred to stress "the essentially co-operative or mass nature of society: Leaving the individual to find his honours in the swoop of creative social forces [...] In comparison to Flaherty's romantic documentary, the realistic documentary, the realistic documentary as he termed it, had a much more difficult task. Grierson [...] offered 
El Patronato de Misiones Pedagógicas era en España el organismo encargado de transmitir la imagen oficial del país según el ideario de la II República, y también realizaba trabajos cinematográficos propagandísticos ${ }^{72}$ Un equipo de cineastas trabajaban así bajo las órdenes de Gonzalo Menéndez Pidal. La imagen que se ofrecía de la "realidad española" tendía a una pretendida objetividad, pero ocultando siempre, como a su modo hacía Grierson en el Reino Unido, el lado negativo y desagradable que toda realidad social puede contener ${ }^{73}$. El doctor Gregorio Marañón ${ }^{74}$, a su vez, presidía tanto el Museo del Pueblo Español como el Patronato de las Hurdes -que se había constituido con motivo del viaje a las Hurdes de Alfonso XIII ${ }^{75}$, en 1922-, y su forma de percibir lo documental era la

his film Difters as a better example. From Flaherty's world it borrowed something of the noble savage and the theme of man against nature but placed in the context of modern industry".

72 SÁNCHEZ VIDAL, Agustín. "De las Hurdes a Tierra sin pan”. Op. cit. Pág. 69, "cuyo principal cineasta y fotógrafo era José Val del Omar, que había producido unos cincuenta documentales para esas instituciones."

73 HERRERA NAVARRO, Javier "Pretexto, contexto e hipertexto en Las Hurdes/Tierra sin pan". Op. cit. Pág. 20.

74 LEGENDRE, Maurice Las Hurdes: estudio de geografia humana. Op. cit. Introducción de Paloma Sánchez y José Pablo Blanco Pág. 12 “[...] Desde esta primera incursión en la zona (1910), viaja a Las Hurdes, exceptuando el periodo de la guerra mundial, visitando paulatinamente, durante los periodos de verano, hasta 1925, todos los pueblos y alquerías de la zona. Dado por finalizado su trabajo presenta su tesis en el año 1927. Preside el tribunal el considerado geógrafo Lucien Gallois, antiguo profesor de la Escuela Normal, formando parte del mismo D. Gregorio Marañón, amigo y compañero de viajes hurdanos del francés". Resulta interesante el valor que el propio investigador concedió en su prefacio (Pág. 90) a la fotografía en relación a las críticas sobre lo limitado que pueda ser su trabajo en relación a la utilización de fuentes bibliográficas: "Responderíamos a esa justa pregunta señalando en primer lugar que una bibliografía, incluso reducida a un pequeño número de ejemplares, puede proporcionar un número bastante abundante de citas, y que la coincidencia de diversos autores, entre ellos y con nosotros, produce una presunción de veracidad bastante grande. Esta presunción se ve reforzada aún más cuando las ilustraciones fotográficas, que esas sí que no mienten, acompañan a las afirmaciones de los viajeros. Pero aún existe otro medio de control, que llega más lejos y es mucho más profundo, y que proporciona la crítica interna de nuestro estudio".

75 En la relación del viaje de Unamuno con Legendre en 1914 se llegan a reflejar estas palabras por su autor: "Y siempre las quejas. "Por aquí debía de venir el rey a comer lo que comemos", decía una mujer que, si no era vieja, lo parecía. Y decialo en muy claro y muy neto castellano" (UNAMUNO, Miguel de. "Las Hurdes" Andanzas y visiones españolas Op. cit Pág. 264) La posición personal de Unamuno sobre la materia posiblemente se deja ver mejor en este pasaje: "La pobre gente hablaba de su vida mansa, humilde, resignadamente. Me entró la duda de si las quejas eran rituales, eco de lo que han oído a los que se constituyen en sus abogados, o una forma más de nuestra característica quejumbrosidad española, de esta detestable manía de pordioseros de estar siempre lamentándonos de nuestra suerte y la de nuestra patria. (Op. cit. Pág. 258-259) El 
propia del folklorismo y de la pedagogía científica que mostrase el lado amable de la vida ${ }^{76}$. Se hallaba así, también lejos de los tres principios básicos que John Grierson había fijado para el género dentro de sus finalidades:

That documentary represented a new and vital art form for observing and selecting from life itself [...] that real persons playing their own roles in life were preferred over actors imposed [...] and that the materials and stories taken from real life could give a greater power of interpretation than anything conjured in a studio. ${ }^{77}$

La película de Luis Buñuel fue estrenada en el Palacio de la Prensa de Madrid, en diciembre de 1933, sin sonorizar ${ }^{78}$, y fue inmediatamente prohibida por las autoridades republicanas españolas ${ }^{79}$. No se volvería a exhibir en Madrid hasta

espectáculo de la miseria hurdana y la esforzada lucha del hombre con la naturaleza era una materia que ya había llamado algo la atención, en Francia es de suponer que gracias a los estudios de Legendre y a otras relaciones de viajeros, pero quizás estaba destinada a tener un plano escasamente relevante, en tanto que en ese verano de 1914 acababa de empezar la Gran Guerra. "Sí, es hondamente humano el que estos pobres hurdanos se aquerencien y apeguen a aquella tierra que es, más que su madre su hija. Legendre me decía que eran el honor de España. Y no es paradoja. Han hecho por sí, sin ayuda, aislados, abandonados de la Humanidad y de la Naturaleza cuanto se puede hacer". (Op. cit. Pág. 255) Materia que, incluso hoy en día, a pesar de haberse olvidado tantas cosas, quizás por ser poco mediáticas, podría seguir siendo objeto de actualizados debates.

${ }^{76}$ HERRERA NAVARRO, Javier "Pretexto, contexto e hipertexto en Las Hurdes/Tierra sin pan". Op. cit. Pág. 21. "Palabras del doctor Marañón en el cineclub acerca de la vanguardia y el cinematógrafo". Gaceta Literaria, núm. 83 (1930) "El doctor Maranón, a la sazón presidente del Patronato de Las Hurdes, en las palabras de presentación en el cine-club de la Gaceta Literaria de unos documentales de biología, en las que se trasluce la concepción que tenía del cine espectáculo del que reconoce no ser entusiasta (si bien valorando su enorme influencia en múltiples aspectos de la vida cotidiana) pero al que augura, en su versión cultural y científica "como ocurre en esos incisos documentales que nos sirven entre las grandes películas", una gran eficacia pedagógica”.

77 MURPHY William T. Robert Flaherty: a guide... Op. cit. Pág. 83.

${ }^{78}$ SÁNCHEZ VIDAL, Agustín. "De las Hurdes a Tierra sin pan”. Op. cit. Pág. 46-47. "Cobra su forma definitiva en unos estudios parisinos en diciembre de 1936, gracias al concurso del cónsul español Luis Araquistáin y el productor Pierre Braunberger. Es entonces cuando se añade al montaje mudo de 1933 el comentario aludido, complementado musicalmente por la Cuarta Sinfonía de Brahms [...] se termina con esta apelación: "Con la ayuda de los antifascistas de todo el mundo la tranquilidad y la felicidad dejarán paso a la guerra civil y con ellos desaparecerán para siempre los focos de miseria que esta película les ha mostrado."

79 SÁNCHEZ VIDAL, Agustín. "De las Hurdes a Tierra sin pan”. Op. cit. Pág. 48-51. "El realizador guardaba entre sus papeles dos comentarios escritos de Las Hurdes, uno en francés y otro en español. El primero [...] está datado el 19 de marzo de 1934 y sirvió posteriormente como base para la locución que, junto con la Cuarta Sinfonía de Brahms, 
abril de 1936, tras el triunfo en las elecciones del Frente Popular, pero un punto importante debe ser resaltado como es que la película se identificó a sí misma sin utilizar en sus propios títulos de crédito las palabras documento o documental. Buñuel ofrece así su trabajo al público con la escueta referencia:

\author{
LAS HURDES \\ una película de Luis Buñuel ${ }^{80}$
}

Sin alusión alguna, por tanto, a la palabra documental que, como hemos visto, ya tenía una carga connotativa institucional u oficialista. Y Buñuel, ante la prohibición oficial, se entrevistó con el doctor Marañón para conseguir el permiso de explotación del film:

Pensábamos que Marañón, con su prestigio y su cargo, nos ayudaría a conseguir el permiso para explotar la película que, naturalmente, había sido prohibida por la censura. Pero su reacción fue negativa.

¿Por qué enseñar siempre el lado feo y desagradable? preguntó. Yo he visto en Las Hurdes carros cargados de trigo. (falso -apostilla Buñuel: los carros sólo pasaban por la parte baja, por la carretera de Granadilla y eran escasísimos). - ¿Por qué no mostrar las danzas folklóricas de La Alberca que son las más bonitas del mundo? Respondí a Marañón que, al decir de sus habitantes, cada país tiene los bailes más bonitos del mundo y que él demostraba un nacionalismo barato y abominable. Después de lo

configura la banda sonora de la película que, por supuesto, fue rodada in sonido y carece de cualquier otro efecto o ruido [...] hay algunas diferencias entre ambas versiones del comentario [...] correspondió al MoMA velar por la difusión de Las Hurdes a través de su versión en inglés [...] El negativo de la película terminó siendo destruido en el transcurso de la Segunda Guerra Mundial, pero a través del MoMA Buñuel se hizo con una copia de su documental hurdano, bien que defectuosa, censurada y con el título de Unpromised Land."

80 La cita procede del Desglose en fotogramas del documental Las Hurdes / Tierra sin pan; publicado por la Junta de Extremadura. Consejería de Cultura y Patrimonio y el Museo Extremeño e Iberoamericano de Arte Contemporáneo (Pág. 77) Aun cuando ahora se publique el desglose en fotogramas presentando el trabajo de Buñuel como "Desglose en fotogramas del documental" esa es una forma de presentar la película que es propia de la crítica posterior, pero no deriva directamente de la propia película. El film, como puede comprobarse, no utiliza esa palabra para referirse a sí mismo. 
cual me marché sin añadir una palabra y la película siguió prohibida. ${ }^{81}$

En 1934 Robert Flaherty presentó Man of Aran, cuyo rodaje le tuvo ocupado desde que dejara de trabajar para la propaganda institucional del Reino Unido. El pretexto literario para dicho trabajo -como la tesis y quizás otras experiencias de Legendre lo fuesen para Buñuel- fue el estudio de John Millington Synge, The Aran Island (1907) que había vivido entre 1898 y 1902 en la isla irlandesa para investigar el idioma y las costumbres de sus habitantes expresando creativamente su forma de vida. El escritor dublinés había publicado ese trabajo y también una obra teatral, Riders to the Sea, para describir poéticamente una cerrada sociedad de pescadores, temerosa de los extraños y llena de supersticiones y mitología. Como se ha señalado:

Synge provided a clear literary expression of some aspects of Aran life that became parts of the film suchs the gathering of seaweed and growing food from the impoverished soil. Synge's one act play Riders to the Sea (1904), set in the Aran Islands, vividly dramatized in dialogue the life and death struggle between man and the sea that Flaherty hoped to create in images ${ }^{82}$

81 HERRERA NAVARRO, Javier "Pretexto, contexto e hipertexto en Las Hurdes/Tierra sin pan”. Op. cit. Pág. 21. Y también, con alguna divergencia, en Buñuel por Buñuel de Tomás Pérez Turrent y José de la Colina. Y vease también UNAMUNO, Miguel de. "Las Hurdes" Op. cit. Marañón parece coincidir con algunas de las opiniones vertidas por Unamuno en la relación del viaje que realizó con Maurice Legendre en el verano de 1914: “¿Para qué habríamos de entrar en uno más de esas miserables mazorcas de tugurios? ¿A qué conduce apurar el espectáculo de la miseria? Además no íbamos a hacer estadística, ni menos sociología. Y Dios les libre a las Hurdes de que caiga en ellas un sociólogo" (Pág. 267) “¿Tuve razón? Porque ver por qué esos pobres heroicos hurdanos se apegan a su tierra: porque es "suya". Es suya en propiedad. [...] Y prefieren mal vivir, penar y arrastrar una miserable existencia en lo que es suyo, antes que bandearse más a sus anchas teniendo que depender de un amo y pagar una renta". (Pág. 273-274) "Pues la pobre tierra cultivada de Las Hurdes es la hija de dolores, de afanes, de sudores, de angustia sin cuento de esos heroicos españoles a quienes se llama salvajes. Ellos la han hecho”. (Pág. 275)

82 MURPHY William T. Robert Flaherty: a guide... Op. cit. Pág. 26 "Only in this case he had to reconstruct it even to the point of teaching the islanders to hunt the basking shark since their generation had never know how". / HERRERA NAVARRO, Javier "Pretexto, contexto e hipertexto en Las Hurdes/Tierra sin pan". Op. cit. Pág. 30 "Sobre todo en lo que atañe a la "ficción de la muerte", única cosa en la que parece existir licencia para mentir: las muertes ficticias de los niños y las mulas, la madre no verdadera del niño muerto, el tiro real a la cabra despeñada, etc... hechos todos ellos por los cuales los defensores de la ortodoxia objetivista del género documental le han negado (con razón) a la película su carta de naturaleza tachándola de tendenciosa, juicio en el que coinciden plenamente con la opinión del mismo Buñuel”. 
Buñuel y Flaherty coincidieron así creativamente por caminos coetáneos, pero separados, y divergentes en algunos puntos relevantes, cuyo nexo de unión quizás se halle en Synge. Su obra Riders to the Sea, a su vez, también pudo ser tenida en cuenta por Federico García Lorca en Bodas de sangre debido a la traducción de Juan Ramón Jiménez y Zenobia Camprubí (Jinetes hacia el mar) ${ }^{83}$. Flaherty y Buñuel, convivieron con los habitantes de esos mundos tan ajenos aún a la civilización industrial y consiguieron la colaboración activa de los protagonistas utilizando el atractivo de una pequeña -o grande, según se mire- recompensa material o económica que incentivase la participación de las personas de carne y hueso -tanto en la comarca extremeña ${ }^{84}$ como en la isla irlandesa ${ }^{85}$ - pues habrían de representar sus propios papeles en la vida real como ficticios. Y ambos directores se concedieron a sí mismos permiso puntual para lo que podríamos llamar mentir para contar la verdad. Los habitantes de los dos distantes lugares representaron así sus papeles pero, como en toda representación dramatizada, en ambos casos se dio el ilusionismo y el engaño, especialmente en las escenas que hubieron de aludir a la ficción de la muerte ${ }^{86}$

Las críticas que recibió Robert Flaherty por Man of Aran fueron las más severas que recibiera en toda su carrera y en algunos aspectos recuerdan las que recibió J.M Synge. Su relectura nos permite ahora ver las diferencias con Las Hurdes / Tierra sin pan y la diferente perspectiva que tenía Buñuel de algunos problemas que planteaba la raíz "doc" en relación al cine. Quizás se tratase de problemas similares, pero referidos a sus respectivos contextos nacionales pueden parecer problemas diferentes.

Man's struggle with Nature is incomplete unless it embraces the struggle of man with man. [...] No less than Hollywood Flaherty is busy turning reality into romance. The tragedy is that being a poet with a poet's eye, his lie is the greater, for he can make the romance seem real.

Man of Aran is escapist in tendency more so probably, than any previous Flaherty production.

83 SAINERO SÁNCHEZ, Ramón Lorca y Synge ¿Un mundo maldito? Madrid Edit. Universidad Complutense, 1983. Sobre la posible influencia de Synge en Lorca puede consultarse esta publicación.

84 SÁNCHEZ VIDAL, Agustín. "De las Hurdes a Tierra sin pan”. Op. cit. Pág. 45. Traducción del inglés de Sánchez Vidal: "Conferencia de Luis Buñuel en 1940 (Universidad de Columbia) Todas las tomas que van a ver ustedes en la película tuvieron que ser retribuidas. Nuestro presupuesto era modesto, pero por fortuna se correspondía con las escasas pretensiones de esta pobre gente."

85 MURPHY William T. Robert Flaherty: a guide... Op. cit. Pág. 25. "The fishermen of Aran braved the seas in a fragile, oar driven craft called a "curragh" [...] Flaherty paid then to do it, and the greater the risk the more he paid".

${ }^{86}$ MURPHY William T. Robert Flaherty: a guide... Op. cit. Pág. 23. 
Flaherty would have us believe that there is no class struggle on Aran, despite ample evidence to the contrary [...] no mention, as Ivor Montagu said in the Daily Worker, of the absentee landlords who sent men to tear down their huts and scatter their in default of payment for things they made themselves ${ }^{87}$.

No se trataba de la primera película de ninguno de ellos, pero en el caso de Buñuel sí era la primera película en la que realizaba un trabajo no onírico o ficticio, como lo fueron Un perro andaluz y La Edad de Oro. La actitud de Buñuel, no obstante, es muy diferente a la de Flaherty y también a la de Synge porque denuncia, mostrando lo feo y lo corrosivo, la situación que ha propiciado la existencia de lo feo y desagradable sin atender a la dimensión optimista de lo épico, la aventura que contrasta con el sentido fatalista de la vida que tenían los habitantes de Aran. Aquello que condujo a Flaherty a enseñar a los isleños las técnicas de pesca que ya tenían olvidadas. Pero no lo hace para responder a los ideales pedagógicos de la II República; se podría plantear si lo hizo para complacerse en los aspectos más negros de la realidad como, a su modo, hiciese Quevedo en su tiempo, aunque sólo con escritura. Lo que cambia esencialmente, es el medio: el cine, que parte de un libro, de un texto y de unas fotografías, la mirada de otro, que se han de replicar. La investigación de Legendre forma parte, o es pretexto, tanto del viaje de Alfonso XIII como de Las Hurdes/Tierra sin pan. En todo caso creo que se puede afirmar que lo hizo para denunciar una situación paralela a la imagen que se transmitía desde la cultura oficial, aunque eso fuese así inicialmente sin llegar a un compromiso explícito con una opción política determinada dentro del republicanismo español. Quizás sólo pretende mostrar su versión de los hechos, aunque eso es materia abierta; su análisis puede depender de la idea que se tenga de la utilización posterior del resultado, de la función que la película cumplió como propaganda ${ }^{88}$, sobre todo a partir del momento en el que se

87 MURPHY William T. Robert Flaherty: a guide... Op. cit. Pág. 71. Citando, en la primera cita, a Ivor Montagu (Daily Worker) y en la segunda Ralph Bond (Cinema Quaterly, 1934) Lo cual puede que no sea muy diferente de alguna de las críticas que recibiera Synge sobre la obra que sirvió de pretexto. SAINERO SÁNCHEZ, Ramón Lorca y Synge ¿Un mundo maldito? Op. cit. Pág. 93, 101-102 y 318. "Si leemos con detenimiento The Aran Islands y todas sus narraciones sobre Irlanda, de hechos reales acaecidos durante sus viajes por la isla, veremos como una prosa sencilla y genial expresa la forma de vivir de este pueblo sin el más leve asomo de reproche o deseo de crítica. [...] "la mayoría considera que la obra de Synge es eminentemente artística y que no es su verdadera intención la de profundizar en una crítica social contra el pueblo irlandés [...] Synge no desea representar la vida en las ciudades irlandesas con sus problemas políticos y sociales [...] Prefiere hablarnos de la vida en el campo y en el mar".

88 HERRERA NAVARRO, Javier "Pretexto, contexto e hipertexto en Las Hurdes/Tierra sin pan”. Op. cit. Pág. 20. 
añadieron sus elementos sonoros en otro contexto político, muy diferente al de su rodaje y su prohibición. Pero la oposición al orden establecido mediante su visión perseguía la subversión del mismo en su conjunto, mediante una instancia previa: la inversión de los elementos que han de conferir fuerza normativa al discurso dominante. Así, Buñuel, además del pretexto de Legendre, utiliza como referente el viaje a la región hurdana del rey Alfonso XIII en $1922^{89}$, pero invirtiendo su sentido (realizando lo que por Javier Herrera se denomina el anti-viaje) físico y espiritual, pero como para registrarlo no tiene más remedio que inscribirse dentro de la estela del documental invierte las normas del género. En consecuencia realiza el anti-documental ${ }^{90}$. El mecanismo que emplea es la superposición tendente a crear una nueva ilusión dual y fluyente de la realidad profundamente significativa, un simulacro en suma del propio discurrir de la vida, dualidad de la que surge su lenguaje $^{91}$. Pero la articulación de la película se organiza en tres niveles bastante diferenciados: el realista -que constata unos hechos-, el dramático -que plantea el conflicto narrativo: ser humano o naturaleza, vida o muerte, ser humano o institución, ser humano contra ser humano-, y el subconsciente -que sumerge al espectador en una dimensión irracional o simbólica ${ }^{92}$. Que, por otra parte, no son aspectos totalmente ajenos a la forma de plantear las cosas de Flaherty, aunque el norteamericano no plantee directamente la dialéctica de los seres humanos entre sí o con las instituciones, y el nivel irracional o simbólico sea quizás más acusado en Luis Buñuel.

Iris Barry, la directora de la Filmoteca del Museo de Arte Moderno de Nueva York, les entregó a Robert y Frances Flaherty una copia de Las Hurdes / Tierra sin pan, estableció correspondencia con Buñuel y el 6 de abril de 1940 le dirigió esta carta tan reveladora:

Antes de recibir su carta ya había mostrado Tierra sin pan a Robert Flaherty. Sin duda Vd. Sabe quien es Flaherty. Se ha quedado maravillado, conmovido por la película. [...] Dice que, sin duda usted hará aquí en América películas de las que ninguna otra persona sería

89 SÁNCHEZ VIDAL, Agustín. "De las Hurdes a Tierra sin pan”. Op. cit. Pág. 41. "La publicidad de que se rodeó la visita regia en junio de 1922 impulsó decisivamente la notoriedad de la comarca, ya que con tal motivo se publicaron en la prensa española numerosas fotografías, entre ellas las muy elocuentes de José Campúa. Asimismo, el operador Armando Pou rodó un cortometraje que se custodia en la Filmoteca Nacional. Es el antecedente cinematográfico más inmediato al rodaje de Buñuel, aunque su talante oficialista y la obligada preeminencia concedida a la figura del monarca lo alejen totalmente del proceder fílmico de Tierra sin pan."

90 HERRERA NAVARRO, Javier "Pretexto, contexto e hipertexto en Las Hurdes/Tierra sin pan". Op. cit. Pág. 23.

91 HERRERA NAVARRO, Javier "Pretexto, contexto e hipertexto en Las Hurdes/Tierra sin pan". Op. cit. Pág. 56.

92 SÁNCHEZ VIDAL, Agustín. "De las Hurdes a Tierra sin pan”. Op. cit. Pág. 56. 
capaz. Perdóneme por haberla mostrado. Con todo, no estoy de acuerdo con usted pero si insiste suprimiré por ahora la película. ¿Le importaría, no obstante, dar una conferencia a mis estudiantes, totalmente en privado, permitiéndome mostrar la película esta vez sólo? ${ }^{93}$

Las respectivas actitudes creativas de ambos puede que conduzcan al cambio de mentalidad que se produjo en el siglo XVII en su respectivo contexto literario y cultural. Tanto si valoramos la actitud de Flaherty en el mundo anglosajón: la propia del explorador que atisba algo geográficamente novedoso que cambia un prejuicio $^{94}$-los que, por ejemplo, no abandonaron a Legendre en su investigación-, o bien si valoramos la mentalidad de los políticos y los escritores de ficción, podemos apreciar que las actitudes de entonces acaso no sean muy diferentes a las de quienes tuvieron que definirse ante lo documental -en este último caso cinematográfico- en el siglo $\mathrm{XX}^{95}$. Por un lado se da la mentalidad del explorador, con una mirada aventurera e inocente ${ }^{96}$, y por otro la del político, el crítico y disconforme con su tiempo, que con una mirada intencionada tiene una receta diferente a la del gobierno para sanar al enfermo: el país, la sociedad, la república, etc... El artificio onírico de Los sueños de Quevedo no se halla tan lejos de Las

93 SÁNCHEZ VIDAL, Agustín. "De las Hurdes a Tierra sin pan”. Op. cit. Pág. 50. El director aragonés dio esta conferencia en la Universidad de Columbia y trabajó luego en el Departamento de Documentalismo del Museo de Arte Moderno de Nueva York.

94 MURPHY William T. Robert Flaherty: a guide... Op. cit. Pág. 84 "Grierson, perhaps more than anyone, propiciated the image of Flaherty's innocence [...] The British documentary went off in different direction, motivated by the problems that its filmmakers confronted daily. Grierson admitted that they were propagandists, helping the working man to understand the technological society [...] This path was taken up by government and other institutions, each with the gentler half of my head that Flaherty's path was right and the other wrong."

95 SÁNCHEZ VIDAL, Agustín. "De las Hurdes a Tierra sin pan”. Op. cit. Pág. 66. "El término "documental" debe referirse siempre a Tierra sin pan con todas las precauciones propias de su peculiar estatuto dentro del género Si tal adscripción casi nunca es sinónimo de mera transmisión en bruto de la realidad, menos todavía debe hacerse con un cineasta de las características de Buñuel."

96 MURPHY William T. Robert Flaherty: a guide... Op. cit. Pág. 87 y 89 "Frances Flaherty wrote about her husband: "Nonpreconception... as a method of discovery and as a process of filmmaking was Robert Flaherty'contribution to the motion picture. Everything flowed from that. Robert Flaherty was a mystic of the modern life, in his approach to a powerful machine he took the scientist's discipline $[\ldots]$ in order to come to the mystic's ecstasy and delight, and to his wisdom. [...] He never remained an explorer in the true sense of the word, though he always claimed he was [...] was artist whose temperament antagonized corporations, institutions, and governments agencies. He needed someone to intercede on his behalf in order to protect him from practicalities of film sponsorship and production [...] took the money but felt little obligation to the sponsor, only to his conscience as an artist". 
Hurdes/Tierra sin pan. Los pasos de lo creativo, en este último caso, parten de una estrategia que es la más característica de la tradición realista, tanto en literatura como en pintura, que disimula, a través de sus evidentes excesos, una visión amarga y fatalista del mundo. Aunque la exageración proceda en este caso, en cierto modo, del punto de partida, del pretexto de un extranjero a su país -de la mirada de otro- y de la simple y llana descripción de la realidad ${ }^{97}$.

\section{CONCLUSIONES}

En los años veinte y treinta del siglo XX convivieron generaciones que habían conocido un mundo en el que los ingenios destinados a la reproducción de la imagen y el sonido aún no tenían gran presencia en la sociedad y en la opinión pública, con una nueva generación que había nacido dentro de la presencia de nuevas aplicaciones, ya masivas, de los ingenios destinados a la reproducción de la imagen y el sonido.

Esa nueva generación tuvo que romper sus lazos con las anteriores y así ocurrió, tanto en España como en el Reino Unido: Dalí, Lorca y Buñuel o T.S. Eliot y Robert Flaherty en EEUU y Reino Unido tuvieron por ello que tomar posiciones frente a problemas comunes. Coincidieron entre sí en desmarcarse de sus referentes inmediatos, revisando crítica y creativamente a los clásicos de sus respectivas tradiciones, tanto en su literatura como en las artes plásticas. Sus referentes comunes se hallaban en el siglo XVII en el que se hallaba igualmente el origen del orden social que se venía a romper y en el que tenían su origen experimental los propios ingenios desarrollados por el positivismo científico que daba lugar a nuevas realidades industriales y civilizatorias.

Estos creadores supieron interpretar esos cambios, aunque, cada uno de ellos, a su modo, con un gran sacrificio personal. Coincidieron en revisar o recomponer, dentro de sus acusadas personalidades, los lazos creativos y críticos con determinados aspectos de las artes que tenían que ver con la forma en la que se producía tecnológicamente la captación y reproducción de la realidad. Las generaciones nacidas y educadas en el XIX, habían tenido suma precaución en la utilización de la voz documento en los textos legales o jurisprudenciales de su tiempo, tanto en España como en el Reino Unido, también en los procesos de elusión consciente del vocablo que son más difíciles de captar. Dentro de ello los vocablos con raíz "doc" fueron especialmente utilizados -o conscientemente eludidos, lo cual es quizás más significativo- por juristas e historiadores de finales del XIX y principios del XX -gestores y creadores de la verdad oficial como Alonso Martínez o Abraham Stoker-y después, en el periodo de entreguerras del siglo XX, los creadores literarios y críticos -como Lorca o T.S. Eliot- rivalizaron

97 HERRERA NAVARRO, Javier "Pretexto, contexto e hipertexto en Las Hurdes/Tierra sin pan”. Op. cit. Pág. 33. 
en esta materia con los creadores y críticos de las diversas artes plásticas y audiovisuales (Buñuel, Flaherty o Dalí son buenos ejemplos de ello, aunque pudieron haberse empleado otros) en la génesis de la cultura icónica que se ha impuesto en Occidente tras la Segunda Guerra Mundial y la Guerra Fría. Para todos estos autores, sin embargo, fue necesario atender a los clásicos de sus respectivas tradiciones estéticas y políticas, en tanto que los autores del siglo denominado "de hierro", en su día, se hallaron igualmente inmersos en unas nuevas formas del poder, tan desconocidas para ellos como acaso lo fueran las nuevas formas del poder institucional para quienes ya son nuestros clásicos del siglo XX.

Una aproximación a estas materias es posible con un tratamiento interdisciplinar. Los referentes utilizados son sólo autores o agentes y hechos históricos puntuales, aunque siguen manteniendo, algunos de ellos, su capacidad de subyugar al lector, al oyente o al espectador. Quizás no sea de suponer que sus respuestas críticas o creativas sean extrapolables a nuevas situaciones o problemas creativos, críticos o jurídicos -por ejemplo, los referentes a propiedad intelectual-, que se generan con la aparición de otras nuevas aplicaciones tecnológicas. Pero no hay demasiados precedentes que se puedan considerar válidos como ejemplos de cambios generacionales complejos en esta materia. Su estudio no carece de alguna utilidad, en todo caso, si puede servir para conocer y apreciar mejor las divergencias y las distintas variables que se pueden producir en la utilización de los vocablos con raíz "doc", documento o documental, en español o en otros idiomas, por los diversos contextos y finalidades en los que, de hecho, dichas palabras se utilizan.

\section{REFERENCIAS BIBLIOGRÁFICAS}

ALLEN, Carleton Kemp Las fuentes del Derecho inglés. Traducción de Antonio Ortiz. Madrid Instituto de Estudios Políticos, 1969.

AZAÑ DÍAZ, Manuel Diarios, 1932-1933 “Los cuadernos robados” Barcelona Edit. Crítica, 1997.

BELDFORD, Barbara. Bram Stoker A Biography of the Author of Dracula Londres Phoenix Giant \& Orion Books Ltd, 1997.

BUÑUEL, Luis. "LUIS BUÑUEL "metteur en scène" cinematogràfic, del qual pot esperar molt el cinema europeu, i les produccions del qual aviat seran revelades al públic, ha contestat a Salvador Dalí, i per a "L’Amic de les Arts" el següent qüestionari”. En L `Amic de les Arts Sitgers núm. 31, abril 1929: Pág.16

- Mi último suspiro. Barcelona Plaza y Janés, 1982.

CARMONA, Ángeles Góngora Ya (z) Toledo Consejería de Cultura, Turismo y Artesanía de la Junta de Castilla-La Mancha, 2009.

CARR, Edward Hallet. What is History? Londres Penguin Books, 1964.

DALÍ, Salvador. "El poeta en la platja d'Empuries vist per Salvador Dalí” En L 'Amic 
de les Arts Sitges núm. 15, junio $1927 . \quad$ Pág. 45.

- "La fotografía pura creació de l'esperit". En L`Amic de les Arts Sitges núm. 18, septiembre 1927. Pag. 90-91.

- “Els meus quadros del saló de Tardor”.En L `Amic de les Arts Siges núm. 19, octubre 1927: Addició al núm. 19.

- "L`alliberament dels dits..." y "Documentals". En L'Amic de les Arts Sitges núm. 31, abril 1929: Pág. 6-10.

DIDI-HUBERMAN, Georges. Pueblos expuestos, pueblos figurantes Traducción de Horacio Pons Buenos Aires Texturas, 2014.

ELIOT T.S. "Tradition and the Individual Talent" En The Sacred Wood (1920) y en Egoist (1919) Norton Anthology of American Literature. Vol. II. Nueva York / Londres: W.W. Norton \& Company, 1985. Pag. 1273-1276.

EMERY, Edwin \& EMERY, Michael. The Press and America, An Interpretative History of the Mass Media Englewood Cliffs Prentice-Hall Inc, 1988.

EIGHTEEN-BISANG, Robert \& MILLER, Elizabeth Bram Stoker's Notes for Dracula. A Facsimile Edition. Philadelphia Rosenbach Museum \& Library Mc Farland, 2008.

GARCÍA LORCA, Federico. "Reyerta de gitanos" En L'Amic de les Arts Sitges núm. 15 junio 1927. Pág. 45.

- Obras completas. Madrid: Edit. Aguilar, 1971.

HARDY, Forsyth. Documentario e realtá. Traducción de Fernaldo di Giammatteo. Roma: Bianco e Nero Editore. 1947.

INSENSER, Elisabet. La fotografía en España en el periodo de entreguerras (1914-1939) Gerona CCG Ediciones \& Centre de Recerca i Difusió de la Imatge del Ajuntament de Girona, 2001.

LEGENDRE, Maurice. Las Jurdes: étude de géographie humaine. Bordeaux Gounouihou, 1927. - Las Hurdes: estudio de geografia humana. Traducción de Enrique Barcia Mendo Introducción de Paloma Sánchez Miguélez y José Pablo Blanco Carrasco. Coda de Luciano Fernández Gómez.'Las Jurdes de Legendre: los prejuicios de un hurdanófilo". Mérida Junta de Extremadura Consejería de Cultura \& Editora Regional de Extremadura, 2006

LÓPEZ YEPES, José. La documentación como disciplina: teoría e historia. Pamplona. EUNSA, 1995 - Manual de Ciencias de la Documentación (coord.) "Documentación" Pág.39-73. Ediciones Pirámide, 2002.

SAINERO SÁNCHEZ, Ramón Lorca y Synge ¿Un mundo maldito? Madrid Edit. Universidad Complutense, 1983.

SÁNCHEZ VIDAL, Agustín. "De las Hurdes a Tierra sin pan". En Las Hurdes/Tierra sin pan. Un documental de Luis Buñuel Madrid Junta de Extremadura, 2000. Pág. 38-76.

SÁNCHEZ VIGIL, Juan Miguel. El universo de la fotografía. Prensa, edición, documentación. Madrid Espasa-Calpe, 1999. 
SANTOS TORROELlA, Rafael. "Los Putrefactos" de Dali y Lorca. Historia y antología de un libro que no pudo ser. Madrid Publicaciones de la Residencia de Estudiantes, 1998.

SPOTTISWOODE, Raymond. Gramática del cine. Traducción de Daniel Zlochevsky. Buenos Aires Ediciones Losange, 1958.

STOKER, Bram. Dracula. Nueva York New American Library, 1965.

TORRES, José Manuel. La retina del sabio. Fuentes documentales para la historia de la Fotografía Científica en España. Santander Aula de Fotografía y de la Imagen de la Universidad de Cantabria \& Ayuntamiento de Gerona, 2001.

VALLE GASTAMINZA, Félix del. El análisis documental de la fotografia. http://pendientedemigracion.ucm.es/info/multidoc/prof/fvalle/artfot.htm Universidad Complutense de Madrid, Versión 2001. Consulta: 15-4-2014.

UNAMUNO, Miguel de. "Las Hurdes" En Andanzas y visiones españolas Madrid Aguilar, 1957. Pag. 241-281. 